\title{
Reduced Susceptibility and Increased Resistance of Bacteria against Disinfectants: A Systematic Review
}

\author{
Urška Rozman $^{1, * \mathbb{C}}$, Marko Pušnik ${ }^{1}$, Sergej Kmetec ${ }^{1}{ }^{1}$, Darja Duh ${ }^{2}$ and Sonja Šostar Turk ${ }^{1}$ \\ 1 Faculty of Health Sciences, University of Maribor, Žitna ulica 15, 2000 Maribor, Slovenia; \\ pusnik.marco@gmail.com (M.P.); sergej.kmetec1@um.si (S.K.); sonja.sostar@um.si (S.Š.T.) \\ 2 Chemicals Office of the Republic of Slovenia, Ajdovšcina 4, 1000 Ljubljana, Slovenia; darja.duh99@gov.si \\ * Correspondence: urska.rozman@um.si; Tel.: +386-2-300-47-52
}

\section{check for}

updates

Citation: Rozman, U.; Pušnik, M.; Kmetec, S.; Duh, D.; Šostar Turk, S. Reduced Susceptibility and Increased Resistance of Bacteria against Disinfectants: A Systematic Review. Microorganisms 2021, 9, 2550. https://doi.org/10.3390/ microorganisms 9122550

Academic Editors:

Elisabeth Grohmann and Kornelia Smalla

Received: 26 November 2021 Accepted: 8 December 2021 Published: 10 December 2021

Publisher's Note: MDPI stays neutral with regard to jurisdictional claims in published maps and institutional affiliations.

Copyright: (c) 2021 by the authors. Licensee MDPI, Basel, Switzerland. This article is an open access article distributed under the terms and conditions of the Creative Commons Attribution (CC BY) license (https:/ / creativecommons.org/licenses/by/ $4.0 /)$.

\begin{abstract}
Disinfectants are used to reduce the concentration of pathogenic microorganisms to a safe level and help to prevent the transmission of infectious diseases. However, bacteria have a tremendous ability to respond to chemical stress caused by biocides, where overuse and improper use of disinfectants can be reflected in a reduced susceptibility of microorganisms. This review aims to describe whether mutations and thus decreased susceptibility to disinfectants occur in bacteria during disinfectant exposure. A systematic literature review following PRISMA guidelines was conducted with the databases PubMed, Science Direct and Web of Science. For the final analysis, 28 sources that remained of interest were included. Articles describing reduced susceptibility or the resistance of bacteria against seven different disinfectants were identified. The important deviation of the minimum inhibitory concentration was observed in multiple studies for disinfectants based on triclosan and chlorhexidine. A reduced susceptibility to disinfectants and potentially related problems with antibiotic resistance in clinically important bacterial strains are increasing. Since the use of disinfectants in the community is rising, it is clear that reasonable use of available and effective disinfectants is needed. It is necessary to develop and adopt strategies to control disinfectant resistance.
\end{abstract}

Keywords: antimicrobial resistance; susceptibility; disinfectants; bacteria

\section{Introduction}

Disinfectants, defined as biocides "Main group 1" [1], are an essential tool in combatting the spread of infectious diseases. When used properly and according to the instructions, disinfectants can help prevent pathogens' transmission and spread, especially in nosocomial infections. With the rise of life-threatening infections with antibiotic-resistant bacteria and newly emerging viruses, the use of disinfectants and virucidal sanitizing agents has increased $[2,3]$.

Disinfectants contain one or more biocidal active substances by which harmful organisms are chemically or biologically deterred, rendered harmless or destroyed [4]. In the healthcare sector, in addition to hand hygiene, the disinfection of surfaces is just as crucial to effectively protect patients, healthcare workers and visitors from the transmission of pathogens $[5,6]$. Biocidal products are also used in everyday hygiene, where consumers are offered a wide range of antibacterial cleaners, hygienic dishwashers, anti-sweat textiles, hygiene wipes and hand disinfectants. Most of them contain biocidal active substances in various amounts $[7,8]$. Although personal and household hygiene is often equated with antimicrobial products, regular handwashing without disinfectants is far more essential and sufficient [9]. However, overuse and improper use of disinfectants can accumulate to be reflected in disinfectant resistance, potentially changing our way of life, from compromising food security to threatening our healthcare systems [6].

Antimicrobial resistance has aroused great interest in the scientific and medical community in the case of antibiotics [10-13], but less interest has been paid to disinfectants, 
widely used, mainly in clinical settings [14,15]. Overuse and, more importantly, misuse of disinfectants may reduce the susceptibility of target organisms to clinically important antimicrobials due to cross-resistance and/or co-resistance mechanisms [16-19]. Therefore, it is necessary to pay more attention to the most broadly used disinfectants, i.e., human personal hygiene products, surface/material disinfectants, and algaecides [20,21]. It is advised to use comparable products without these biocidal agents to avoid unnecessary selection pressure of disinfectants on bacteria. Preferably, if a common handwashing agent can deactivate bacteria, there is an incentive to promote such use [22,23].

Decreased susceptibility or even resistance against disinfectants can occur due to various inside and outside cellular mechanisms resulting from bacterial phenotypic and genotypic adaptation [3]. Unlike antibiotics, the mode of action of disinfectants can be unspecific, targeting different processes or sites in bacterial cells and inflicting cell damage to multiple bacteria; hence resistance development is unlikely [24-26]. Nevertheless, bacterial resistance to disinfectants can be created by the mutation or amplification of an endogenous chromosomal gene, by acquiring resistant determinants on chromosomal genetic elements like plasmids, transposons, and integrons [23,27], or due to changes in cell envelope permeability, increased efflux pump expression and the specific mechanisms of phenotypic traits [28]. Another means of bacterial adaptation presents through disinfectant inactivation or neutralization [29] and biofilm formation.

Decreased susceptibility and acquired resistance to disinfectants has been documented [20,30-32], primarily against less reactive active ingredients, such as quaternary ammonium compounds (QAC), biguanides, phenols [2], benzalkonium chloride, triclosan (TCS; polychlorinated phenoxy phenol), chlorhexidine (CHX) [33], didecyl dimethyl ammonium chloride (DDAC) [34], tetracycline and chloramphenicol [35].

This review aims to describe whether mutations and thus decreased susceptibility occur in bacteria during long-term use and exposure to disinfectants.

\section{Materials and Methods}

\subsection{Data Sources and Search Strategy}

We performed a systematic review using the examination, analysis and synthesis of literature and the compilation method. We followed the PRISMA guidelines [36]. The search was performed using search terms in English: (susceptibility OR resistance) AND (disinfectants OR biocides) AND (bacteria OR microorganisms). A literature search was conducted with the databases PubMed, Science Direct and Web of Science. We used the following search limits: research papers published in English related to the research topic until June 2020. We used the same search terms, search limits, inclusion, and exclusion criteria in all the databases. Predetermined inclusion and exclusion criteria were applied as presented in Table 1.

\subsection{Study Selection}

After revision of the databases, the results $(n=11,308)$ were exported and compiled with Mendeley's reference management software. We also performed hand searching and included 88 articles. Mendeley's automated process removed duplicates $(n=3318)$, followed by a manual search to identify and remove additional duplicates. The authors screened all abstracts $(n=7990)$. The search focused on articles describing bacteria that developed a substantial decrease in disinfectant susceptibility with known biocide ingredients. There were multiple reasons for excluding studies, mostly for lacking MIC values or disinfectant concentrations. For the final analysis and the review, 28 sources that remained of interest were included and screened based on their full text by two independent reviewers (See Figure 1). 
Table 1. Research strategy inclusion and exclusion criteria.

\begin{tabular}{|c|c|c|}
\hline \multirow[t]{2}{*}{ Databases: } & \multicolumn{2}{|c|}{ PubMed, Science Direct and Web of Science } \\
\hline & Inclusion Criteria & Exclusion Criteria \\
\hline Problem: & $\begin{array}{l}\text { - Bacteria that developed a substantial decrease } \\
\text { in susceptibility to disinfectants with known } \\
\text { biocide ingredients }\end{array}$ & $\begin{array}{l}\text { Bacteria that did not develop a substantial } \\
\text { decrease in susceptibility to disinfectants with } \\
\text { known biocide ingredients }\end{array}$ \\
\hline $\begin{array}{l}\text { Intervention/ } \\
\text { Treatment: }\end{array}$ & $\begin{array}{l}\text { - Susceptibility test (disk diffusion test, } \\
\text { minimum inhibitory concentration) }\end{array}$ & - $\quad$ Susceptibility test results not included \\
\hline Outcome: & $\begin{array}{l}\text { - Reduced susceptibility and increased resistance } \\
\text { of bacteria against disinfectants }\end{array}$ & $\begin{array}{l}\text { - Bacteria without reduced susceptibility and } \\
\text { increased resistance against disinfectants }\end{array}$ \\
\hline Types of research: & $\begin{array}{l}\text { - Research article experimental and } \\
\text { quasi-experimental }\end{array}$ & $\begin{array}{l}\text { - Systematic review articles or other types } \\
\text { of reviews } \\
\text { Duplicates, commentaries, editorials, } \\
\text { conferences, and research protocols }\end{array}$ \\
\hline
\end{tabular}

Search limits

\begin{tabular}{cl}
\hline Timeframe: & Until December 2020 \\
\hline Language: & English \\
\hline
\end{tabular}

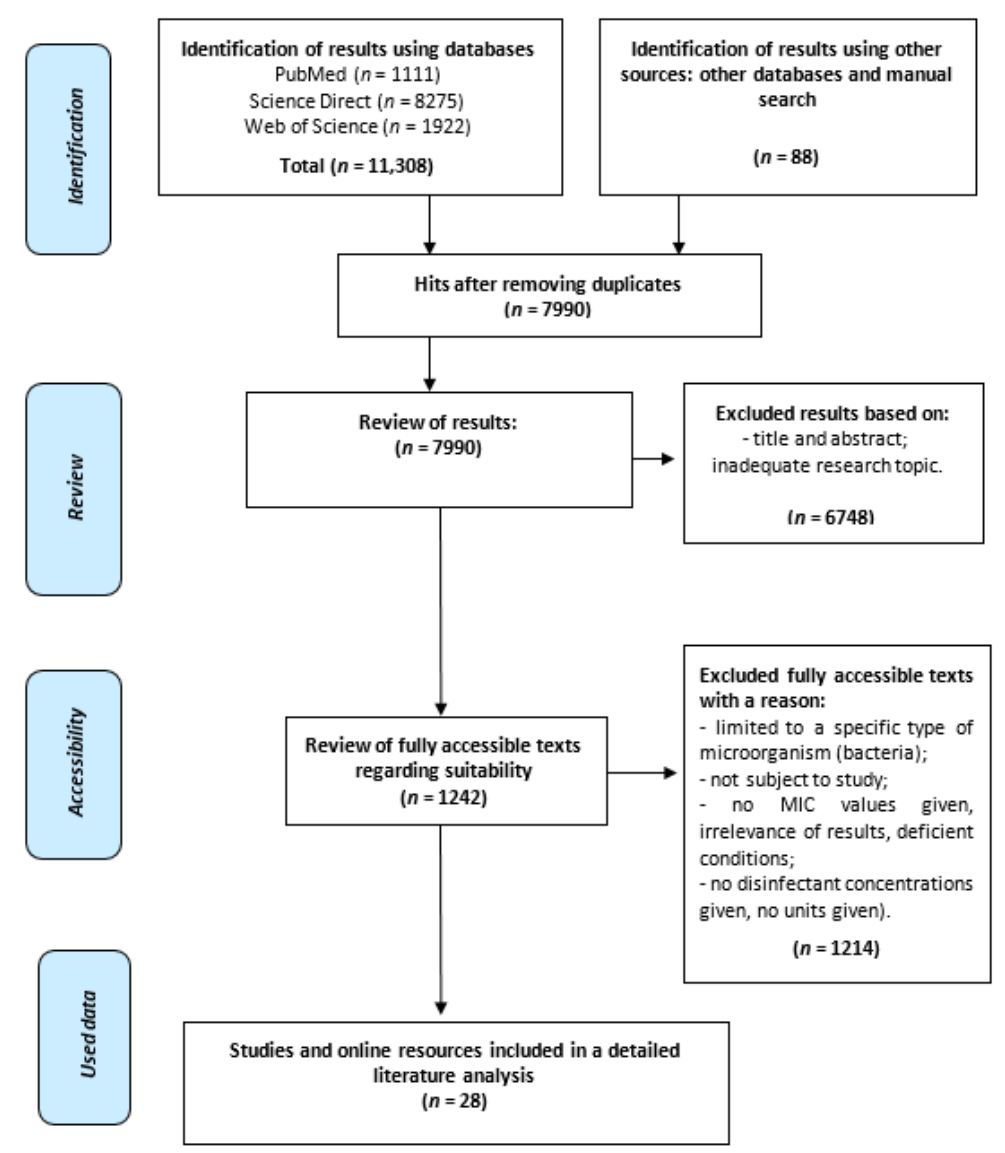

Figure 1. Flow diagram search strategy according to PRISMA recommendations. 


\subsection{Data Extraction and Analysis}

The relevant data were first extracted by MP and checked by UR. The characteristics of the identified relevant sources were presented in a table, where we described the findings from the review and analysis of the relevant literature. The main findings from the identified sources were highlighted. The extracted data included: (1) disinfectant category; (2) publication author(s), year, country, journal; (3) study aim/purpose; (4) main results of the identified research study.

\section{Results}

Articles describing the resistance of bacteria against seven different disinfectants were identified, namely: triclosan (10 articles), peracetic acid ( 2 articles), hydrogen peroxide ( 3 articles), ethanol and isopropanol (1 article), formaldehyde and glutaraldehyde ( 2 articles), chlorhexidine (4 articles), benzalkonium chloride and didecyldimonium chloride (5 articles). For this review, the definition of bacterial resistance to a disinfectant is based on an importantly decreased susceptibility in different tests (e.g., disk diffusion test, minimum inhibitory concentration MIC) reported by the clinical microbiology or research laboratories described in the reviewed studies. All 28 selected publications that met the search criteria are classified in Table 2.

Table 2. Study characteristics of identified research studies about disinfectant resistance.

\begin{tabular}{|c|c|c|}
\hline Author, Year, Country, Journal & Study Aim/Purpose & $\begin{array}{c}\text { Main Results of Identified Research } \\
\text { Studies }\end{array}$ \\
\hline \multicolumn{3}{|c|}{ Triclosan } \\
\hline $\begin{array}{l}\text { Cottell, et al. (2009), } \\
\text { Great Britain and Germany, } \\
\text { Journal of Hospital Infection }\end{array}$ & $\begin{array}{l}\text { Determining the minimum inhibitory } \\
\text { concentrations of triclosan with broth- } \\
\text { and agar-dilution methods. Using the } \\
\text { British Society for Antimicrobial } \\
\text { Chemotherapy guidelines, the antibiotic } \\
\text { susceptibilities were determined. } \\
\text { Exploring further linkages between } \\
\text { triclosan exposure and the emergence or } \\
\text { lack of bacterial antibiotic resistance. }\end{array}$ & $\begin{array}{l}\text { Triclosan MICs were significantly higher for } \\
\text { the mutant strains S. aureus T3 and E. coli } \\
\text { TM3 compared with the parent strains E. coli } \\
\text { ATCC } 8739 \text { and S. aureus NCIMB } 9518 \text {. } \\
\text { Significantly higher MIC was also observed } \\
\text { in the triclosan-tolerant strain A. johnsonii RC } \\
\text { compared to the sensitive counterpart. }\end{array}$ \\
\hline $\begin{array}{l}\text { Byung, et al. (2010), } \\
\text { Great Britain, } \\
\text { Journal of Antimicrobial Therapy }\end{array}$ & $\begin{array}{l}\text { Studying defense mechanisms against } \\
\text { triclosan in mutants derived from the } \\
\text { E. coli strain, which carry the target } \\
\text { triclosan-resistant enzyme, FabI (G93V). }\end{array}$ & $\begin{array}{l}\text { The MIC of triclosan for the E. coli imp } 4231 \\
\text { FabI (G93V) mutant with different } \\
\text { concentrations after } 20 \text { h of exposure resulted } \\
\text { in } 8 \mathrm{mg} / \mathrm{L} \text {. This is approximately } 400 \text { times } \\
\text { higher when compared with the parent } \\
\text { strain, where the MIC was } 0.02 \mathrm{mg} / \mathrm{L} \text {. The } \\
\text { highest MIC of triclosan }(80 \mathrm{mg} / \mathrm{L}) \text { was in } \\
\text { E. coli IFN4. }\end{array}$ \\
\hline $\begin{array}{l}\text { Cameron, et al. (2019), } \\
\text { India, } \\
\text { PLoS One }\end{array}$ & $\begin{array}{l}\text { Identifying the functional mechanisms of } \\
\text { triclosan resistance in waste waters } \\
\text { metagenomes and assessing the } \\
\text { frequency of resistance in clinical isolates } \\
\text { of E. coli and Enterococcus spp. }\end{array}$ & $\begin{array}{l}\text { Three E. coli isolates had up to } 64 \text {-fold higher } \\
\text { triclosan MICs ( } 2 \text { to } 8 \mathrm{mg} / \mathrm{L}) \text { than the original } \\
\text { MICs and were presumed ESBL producers. }\end{array}$ \\
\hline $\begin{array}{l}\text { D'Arezzo, et al. (2012), } \\
\text { Italia, } \\
\text { BMC Research Notes }\end{array}$ & $\begin{array}{l}\text { Evaluating the antimicrobial activity of } \\
\text { triclosan and chlorhexidine digluconate } \\
\text { (also for two commercial disinfectants) } \\
\text { against the epidemic strain of } \\
\text { P. aeruginosa. }\end{array}$ & $\begin{array}{l}\text { An extremely high level of triclosan } \\
\text { resistance (MIC } 2125 \mathrm{mg} / \mathrm{L} \text { ) was observed } \\
\text { for the } P \text {. aeruginosa epidemic strain. The } \\
\text { same strain was susceptible to chlorhexidine } \\
\text { digluconate }(\mathrm{MIC} 12.5 \mathrm{mg} / \mathrm{L}) \text {. The epidemic } \\
\text { strain survived for more than } 120 \mathrm{~h} \text { in the } \\
\text { presence of } 3400 \mathrm{mg} / \mathrm{L}(\approx 1.6 \times \mathrm{MIC}) \text { of } \\
\text { triclosan upon gradual adaptation. }\end{array}$ \\
\hline $\begin{array}{l}\text { Huang, et al. (2016), } \\
\text { China, } \\
\text { Frontiers of Microbiology }\end{array}$ & $\begin{array}{l}\text { Demonstrating the functional } \\
\text { characteristic of triclosan-resistant } \\
\text { enoyl-acyl protein reductase carrier } \\
\text { (FabV) in P. aeruginosa. }\end{array}$ & $\begin{array}{l}\text { The plasmid-bearing strain P. aeruginosa } \\
\text { PAO170 (1fabV) (pSRK-PI and pSRK-PV) } \\
\text { was triclosan resistant; the triclosan MIC was } \\
\text { above } 2000 \mu \mathrm{g} / \mathrm{mL} \text {. }\end{array}$ \\
\hline
\end{tabular}


Table 2. Cont.

\section{Author, Year, Country, Journal}

Forbes, et al. (2015),

Great Britain,

Antimicrobial Agents

and Chemotherapy

Bayston, et al. (2007),

Great Britain,

Journal of Antimicrobial

Chemotherapy

Copitch, et al. (2010),

Great Britain,

International Journal of Antimicrobial Agents

Condell, et al. (2012),

Ireland,

Journal of Proteomics

Webber, et al. (2008),

Great Britain,

Journal of Antimicrobial

Chemotherapy
Antimicrobial triclosan susceptibility testing, cell mobility and morphology in small colonies of Staphylococci.

Determining the antimicrobial activity duration of triclosan-impregnated silicone. Reporting about the development of MRSA resistance during experimental exposure.

Determining the reduced susceptibility to triclosan in the group of S. enterica isolates and to identify and describe the mechanisms of resistance.

In the study, the authors compared the proteomic profile of the susceptible serovar S. enterica Typhimurium with its isogenic triclosan tolerant strain to decode cellular mechanisms that promote biocide tolerance.

The purpose of the study was to describe the mechanisms of triclosan resistance in S. enterica Typhimurium.
Main Results of Identified Research Studies

S. aureus produced small colony variants with decreased triclosan susceptibility (4/ 6 test bacteria) when exposed to triclosan. The susceptibility of strains P0 to P10 increased in MIC (4- to 31-fold) and MBC increased from 3- to 16-fold. ATCC 6538 R1 had a MIC of up to $31 \mathrm{mg} / \mathrm{L}$.

Two of the three MRSA strains showed impaired coagulase production and decreased deoxyribonuclease production. Triclosan MICs increased between 8- and 67-fold (MIC up to $4.0 \mathrm{mg} / \mathrm{L}$ ).

The level of resistance to triclosan was generally low in S. enterica isolates (triclosan range MIC $0.25-4 \mathrm{mg} / \mathrm{L}$ ). Increased efflux activity was observed in multidrug-resistant and triclosan-resistant strains when comparing them to the strains with a reduced susceptibility to triclosan alone.

Changes in the proteome of Salmonella were observed when exposed to sublethal concentrations of triclosan, which gave insights into mechanisms for the response and tolerance.

Three triclosan-resistant phenotypes were classified as low MIC (MIC $<8 \mathrm{mg} / \mathrm{L}$ ), medium MIC (MIC 16-32 mg/L), and high MIC mutants (MIC > $32 \mathrm{mg} / \mathrm{L}$ ). The most resistant mutant was strain L702 with MIC $64 \mathrm{mg} / \mathrm{L}$.

Peracetic acid

Van der Veen and Abee (2011),

Netherlands,

International Journal of

Food Microbiology

Spoering and Lewis (2001),

USA,

Journal of Bacteriology
Studying single and mixed-species biofilm formation (Listeria monocytogenes EGD-e and LR-991), with Lactobacillus plantarum WCFS1 as the secondary species. Determining resistance to benzalkonium chloride and peracetic acid.

Studying biofilms of $P$. aeruginosa wild-type strain PAO1 and comparing its resistance against biocide when comparing it to planktonic cells.
Resistance to benzalkonium chloride is higher in single and mixed-species biofilms than in planktonic grown cells. After exposure for $15 \mathrm{~min}$ to $100 \mu \mathrm{g} / \mathrm{mL}$, mixed-species biofilms are more resistant to benzalkonium chloride than single-species biofilms. The resistance against peracetic acid treatments ( $15 \mathrm{~min}$ to $100 \mu \mathrm{g} / \mathrm{mL}$ ) is also higher in single and mixed-species biofilms than planktonic grown cells, but the differences are less pronounced. When comparing biofilms to logarithmic-phase planktonic cells, biofilms were considerably tolerant to the biocide. On the other hand, stationary-phase planktonic cells were more tolerant of peracetic acid than biofilms. The MBC for all three populations was $400 \mathrm{~g} / \mathrm{mL}$. 
Table 2. Cont.

\begin{tabular}{|c|c|c|}
\hline Author, Year, Country, Journal & Study Aim/Purpose & $\begin{array}{c}\text { Main Results of Identified Research } \\
\text { Studies }\end{array}$ \\
\hline \multicolumn{3}{|c|}{ Hydrogen Peroxide } \\
\hline $\begin{array}{l}\text { Pericone, et al. (2000), } \\
\text { USA, } \\
\text { Infection and Immunology }\end{array}$ & $\begin{array}{l}\text { To determine if Streptococcus pneumoniae } \\
\text { and Haemophilus influenza produce } \\
\text { substances (hydrogen peroxide) that } \\
\text { inhibit the other bacteria's growth. }\end{array}$ & $\begin{array}{l}\text { H. influenzae was most susceptible to growth } \\
\text { inhibition, and killing by } \mathrm{H}_{2} \mathrm{O}_{2} \text { (MIC, } \\
0.4 \mathrm{mM} \text {; MBC, } 0.5 \mathrm{mM} \text { ). } \mathrm{N} \text {. meningitides was } \\
\text { also relatively sensitive (MIC, } 0.4 \mathrm{mM} \text {; MBC, } \\
5.0 \mathrm{mM} \text { ). M. catarrhalis was shown to be } \\
\text { relatively insensitive (MIC, } 1.1 \mathrm{mM} \text {; MBC, } \\
160 \mathrm{mM} \text { ) like Pneumococcus (MIC, } 1.6 \mathrm{mM} \text {; } \\
\text { MBC, } 80 \mathrm{mM} \text { ), which could explain the } \\
\text { ability to survive endogenously produced } \\
\text { hydrogen peroxide. }\end{array}$ \\
\hline $\begin{array}{l}\text { Wesgate, et al. (2016), } \\
\text { Great Britain, } \\
\text { American Journal of Infection Control }\end{array}$ & $\begin{array}{l}\text { Exposure of Staphylococcus aureus and } \\
\text { Escherichia coli to triclosan, chlorhexidine } \\
\text { gluconate solution, hydrogen peroxide } \\
\text { and a hydrogen peroxide-based product. } \\
\text { Determination of the susceptibility by } \\
\text { combining standard efficacy protocols. }\end{array}$ & $\begin{array}{l}\text { Significant increases in antimicrobial } \\
\text { insusceptibility (MIC } 69 \text {-fold; MBC } 74 \text {-fold } \\
\text { increase) were observed when exposing } \\
\text { S. aureus for } 5 \text { min to } 0.0004 \% \text { triclosan.). A } \\
\text { more than } 30 \text {-fold increase in MIC was } \\
\text { observed after E. coli exposure to bisphenol. } \\
\text { No changes in the susceptibility profile (less } \\
\text { than two-fold) were observed when exposing } \\
\text { bacteria to } 0.00005 \% \text { CHG, } 0.001 \% \mathrm{H}_{2} \mathrm{O}_{2} \text { and } \\
0.001 \% \text { Oxy BAC. }\end{array}$ \\
\hline $\begin{array}{l}\text { Lin et al. (2017), } \\
\text { China, } \\
\text { Frontiers of Microbiology }\end{array}$ & $\begin{array}{l}\text { Using a PCR reverse transcriptase } \\
\text { method for the assessment of the } \\
\text { association between efflux pump gene } \\
\text { expression and a reduced sensitivity for } \\
\text { triclosan, chlorhexidine, benzalkonium } \\
\text { chloride, hydrogen peroxide and ethanol. }\end{array}$ & $\begin{array}{l}\text { A variety of susceptibilities to biocides was } \\
\text { observed by the tested isolates. MICs for } \\
\text { triclosan ranged from } 2-256 \mu \mathrm{g} / \mathrm{mL} \text {, for } \\
\text { chlorhexidine } 8-128 \mu \mathrm{g} / \mathrm{mL} \text {, for } \\
\text { benzalkonium bromide } 4-32 \mu \mathrm{g} / \mathrm{mL} \text {, } \\
(1.6-13 \mathrm{mg} / \mathrm{mL}) \text {, for hydrogen peroxide } \\
47-376 \mathrm{mM} \text {, and for ethanol }(60-180 \mathrm{mg} / \mathrm{mL}) \\
\text { at } 7.5-22.5 \% \text { (vol/vol). }\end{array}$ \\
\hline
\end{tabular}

Ethanol and Isopropanol

Pidot, et al. (2018),

Australia,

Science Translational Medicine
In this study, the authors sought to compare the alcohol tolerance of 139 nosocomial $E$. faecium isolates obtained between 1997 and 2015.
Newer clinical isolates of E. faecium were more resistant to alcohol than their predecessors. Using a 70\% isopropanol surface disinfectant, mutated E. faecium isolates were ten times more tolerant to disinfectant than isolates from decades ago. Strain ST796 had a reduced tolerance to isopropanol of $1.14 \log ^{10}$. Four hundred nucleotide positions mutated on two or more pairs of sequences.

Formaldehyde and Glutaraldehyde

The study's main objective was to perform a preliminary examination to detect apparent differences between Salmonella serotypes and isolates, to link them with the resistance to disinfectants, for which there are extensive data regarding Danish fattening flocks.
In MICs of five disinfectants commonly used in the Danish or English poultry sector, few variations were observed. Most differences from the isolates having high MICs were determined when using formaldehyde, but only a few isolates differed from the high MIC isolates when using the other four disinfectants. 
Table 2. Cont.

\section{Author, Year, Country, Journal}

Tschudin-Sutter, et al. (2011),

Switzerland,

Infection Control and

Hospital Epidemiology
Determining the effectiveness of the endoscope cleaning procedure with glutaraldehyde in a Danish hospital against $P$. aeruginosa strains.
Main Results of Identified Research Studies

In samples obtained by endoscopes, $P$. aeruginosa was detected. During the disinfection procedure, a disinfectant based on glutaraldehyde showed no activity against two Pseudomonas outbreak strains when used under standard conditions at the recommended concentration. After reviewing the medical chart, six patients with circulatory and lower respiratory infections had an epidemiological link to the Pseudomonas outbreak strain. The most resistant strain needed the use of concentrations almost three times higher to achieve the same microbicidal effects.

\section{Chlorhexidine}

The isolation of Enterococcal strains from dust samples collected from Portuguese breeding pig establishments.

Braga, et al. (2013),

Portugal,

Veterinary Microbiology

Valenzuela, et al. (2013), Spain, Journal of Food Protection

Akinkunmi and Lamikanra (2012), Nigeria,

Journal of Infection in

Developing Countries

Thomas, et al. (2000),

Great Britain,

Journal of Hospital Infection
Examination of MRSA resistance to commonly used antibiotics and antiseptics in fecal sample isolates from children in the community
The aim was to investigate the effects of sub-MIC concentrations of $\mathrm{CHX}$ on gram-negative bacteria, particularly the $P$. aeruginosa strain, which is known to have an intrinsic resistance to $\mathrm{CHX}$, and the susceptibility of CHX-resistant strains to antibiotics.
The maximum MIC value for benzalkonium chloride and chlorhexidine in VRE isolates was $4 \mu \mathrm{g} / \mathrm{mL}$. This was also the highest MIC value for all the other 41 isolates. The exceptions were two vancomycin-intermediate isolates, with a MIC to chlorhexidine of $8 \mu \mathrm{g} / \mathrm{mL}$.

Triclosan $(250 \mathrm{mg} / \mathrm{L})$ inhibited $98.16 \%$ of isolates. The greatest variability was observed for chlorhexidine (MICs from 2.5 to $2500 \mathrm{mg} / \mathrm{L})$. For the inhibition of $74.57 \%$ of isolates from clinical samples, the required dose of chlorhexidine was $2500 \mathrm{mg} / \mathrm{L}$. Inhibition of Enterococci by copper sulfate was observed in the range $4-16 \mathrm{mM}$. Among MRSA isolates, $68.8 \%, 75.0 \%$, and $100 \%$ were more resistant to benzalkonium chloride, chlorhexidine, and cetrimide than S. aureus NCTC 6571. Among the methicillin-susceptible $S$. aureus isolates, $32.0 \%, 28.0 \%$, and $56.0 \%$ were more resistant to benzalkonium chloride, chlorhexidine gluconate, and cetrimide than $S$. aureus NCTC 6571 . MIC $_{50}$ values for $S$. aureus were $8 \mathrm{mg} / \mathrm{mL}, 4 \mathrm{mg} / \mathrm{mL}$ and $32 \mathrm{mg} / \mathrm{mL}$ for benzalkonium chloride, chlorhexidine and cetrimide, respectively.

After the fourth subculture, growth occurred within $24 \mathrm{~h}$ with a further increase in the MIC in P. aeruginosa strains NCIMB 10421; the MIC was significantly increased from the original $10 \mu \mathrm{g} / \mathrm{mL}$ to more than $70 \mu \mathrm{g} / \mathrm{mL}$. The significance of these findings is still unclear, as the concentration of CHX in clinical use is much higher than that at which the authors obtained resistance. 
Table 2. Cont.

\begin{tabular}{ccc}
\hline Author, Year, Country, Journal & Study Aim/Purpose & Main Results of Identified Research \\
Studies
\end{tabular}

Benzalkonium chloride and didecyldimonium chloride

Nasr, et al. (2018),

Egypt,

American Journal of

Infection Control

McCay, et al. (2010),

Ireland,

Microbiology

Fazlara and Ekhtelat (2012), Iran,

American-Eurasian Journal of Agriculture

He, et al. (2014),

China,

Journal of Medical Microbiology

Yu, et al. (2018),

China,

Frontiers in Microbiology

Ramzi, et al., (2020),

Morocco,

BioMed Research International
The study aimed to evaluate the effect of isolated Pseudomonas exposure, the susceptibility to antibiotics, and to subinhibitory concentrations of two disinfectants, didecyldimonium chloride and sodium hypochlorite.

Determining whether exposure of the population of P. aeruginosa (NCIMB 10421) to higher BAC levels in long-term continuous culture would result in a cross-adaptation to antimicrobials.

Evaluation of the antibacterial effects of benzalkonium chloride commonly used in the food industry, on six major food-borne pathogens.

Studying isolates of BAC-resistant Staphylococci from the community environment with isolation, identification, and detection of BAC resistance genes.

The study examined the effect of BAC adaptation on antimicrobial susceptibility and tolerance to environmental loads and the role of efflux pumps in the adaptation of L. monocytogenes.

Studying the antibacterial activity of quaternary ammoniums synthetic disinfectants for hospital environment isolates: Escherichia coli, Klebsiella pneumoniae, Enterobacter cloacae, Pseudomonas aeruginosa, Acinetobacter baumannii, and Staphylococcus aureus.
The development of antibiotic and biocidal resistant Pseudomonas strains can occur when using concentrations of sodium hypochlorite and didecyldimonium chloride. This study emphasizes the need for strict adherence to standard hospital disinfection policies to achieve adequate prevention and control of healthcare-associated infections. The MICs for all isolates ranged from $0.01 \%$ to $0.02 \%$ for sodium hypochlorite and $0.012 \%$ for didecyldimonium chloride.

A method to enrich a continuous culture of $P$. aeruginosa NCIMB 10421, the MIC $25 \mathrm{mg} / \mathrm{L}$ of benzalkonium chloride was added ( $\mathrm{D}=0.04 \mathrm{~h}-1.792 \mathrm{~h}$ ). The derivative PA-29 (696 h) showed a $>12$-fold reduced susceptibility to the biocide, $\mathrm{MIC}>350 \mathrm{mg} / \mathrm{L}$.

The benzalkonium chloride MIC and MBC ranged between 40 and $45 \mathrm{mg} / \mathrm{L}$ for E. coli. The most susceptible and resistant bacteria were L. monocytogenes and B. cereus (MIC 30 and $35 \mathrm{mg} / \mathrm{L}$ and MBC 140 and $160 \mathrm{mg} / \mathrm{L}$, respectively)

The analysis of resistance genes showed that 41 strains contained qacA/B, 30 strains qacC, 25 strains qacG, 16 strains qacH, and eight strains qacJ. Because the BAC biocide affects these genes, this indicates an associated resistance in Staphylococci. The maximum MIC value for 63 strains of $S$. aureus ranged up to $32 \mu \mathrm{g} / \mathrm{mL}$ for BAC.

In BAC adapted Listeria strains, $18 \mathrm{EtBr}$ strains had a MIC of $200 \mu \mathrm{g} / \mathrm{mL}$, in 5 strains the MIC was $>200 \mu \mathrm{g} / \mathrm{mL}$ and in 2 strains it was $100 \mu \mathrm{g} / \mathrm{mL}$.

The tested disinfectant demonstrated an antibacterial effect against $S$. aureus and S. aureus ATCC 29213 (MIC of $0.25 \mathrm{mg} / \mathrm{mL}$ ); the disinfectant spray showed effects in E. coli, S. aureus, E. coli ATCC 25922, and P. aeruginosa ATCC 27853 (MIC of $4 \mathrm{mg} / \mathrm{mL}$ ) and S. aureus ATCC 29213 (MIC $2 \mathrm{mg} / \mathrm{mL}$ ). Phagosurf $\mathrm{ND}^{\circledR}$ inhibited the growth of S. aureus ATCC 29213 (MIC of $4 \mathrm{mg} / \mathrm{mL}$ ).

Multiple studies have shown an increased MIC from approximately 4- to 60-fold for specific bacteria for the disinfectant triclosan, making it epidemiologically relevant for increased bacterial adaptability and resistance [16,37-45]. The mechanisms for the elevated MIC were various mutations at the genetic level. For E. coli these were: deletion of the $y c j D$ gene [45], mutation at codon 93 of the fabI gene, and mutation of the MarR transcription activator within the marR $A B$ operon c, which regulates the operation of efflux pumps $[41,43]$. For $P$. aeruginosa, there was deletion of the $f a b V$ gene, leading to a decreased fatty acid synthesis and consequent inhibition of the production of acyl-homoserine lactones and 
other virulence factors, such as LasA/LasB, alkaline proteases, phospholipases, lipases, exotoxin A, rhamnolipid and pyocyanin, and a reduced pathogenicity [46]. It also affects the MexCDOprJ gene, PAO1, which encodes 12 RND pumps [47,48]. For S. aureus, intracellular malonyl-CoA inhibits the activity of the transcriptional repressor FapR, which directly interacts with the fabI gene, physiologically regulating its expression. This results in the most common mutations, polymorphisms, within the coding regions of C34T and MO035 in the sa-FabI region $[49,50]$. For S. enterica there was: a mutation in the fabI gene, mutation of the $A c r A B$ and $T o l C$ genes that regulate efflux pumps, and inactivation of the transcriptional regulators ramA and marA [51-53].

For the disinfectant peracetic acid, the MIC was raised four-fold in one of the three bacteria tested (P. aeruginosa), while in the others, there were no significant changes in susceptibility. According to the described example, it could be classified as relevant in the indication of resistance, although the results are currently deficient due to the lack of multiple studies and unequal conditions [54,55]. For E. coli, mutations in the genes erm (B), tet $(M)$, and tet $(L)$ were observed [56].

For the disinfectant hydrogen peroxide, the MIC was also relevantly elevated in only one of the three bacteria studied (A. baumannii) and can be treated as a possible indicator of resistance here as well. However, due to deficient studies and unequal conditions, no conclusion regarding resistance can be made [57-59]. The cause of the elevated MIC were gene mutations. In all bacteria, mutations were in genes that regulate catalase (Kat), alkyl hydroperoxide reductase, and DNA-binding proteins that allow the catalase-reversible mechanism's inhibitory effect on SpxB expression [60,61].

For the disinfectant chlorhexidine, the MIC has risen by almost 32-150 times in multiple relevant studies reviewed, making it epidemiologically relevant for increased bacterial adaptability and resistance, and a research/clinically relevant biocide [62-66]. The causes of the elevated MICs were gene mutations. For Enterocoscus, mutation of the efr $A$ and efrB genes that alter the expression of the EfrAB efflux pump of the ABC family, and hydrophobicity of the bacterial surface were observed $[67,68]$. For $S$. aureus and MRSA, mutations of $q a c A, q a c B, s m r$ and nor A genes were observed [69-72]. For P. aeruginosa, mutation of efflux pump genes, such as MexCD-OprJ and oprH-phoPQ initiated by the stress response factor AlgU [69-74], and a decreased regulation of genes that encode proteins involved in membrane transport, oxidative phosphorylation, electron transport, and DNA repair were observed [75-77].

For the disinfectant benzalkonium chloride in multiple relevant studies reviewed, in three of the four bacteria, the MIC rises only 1-4-fold. This could make it epidemiologically relevant for increased bacterial adaptability and resistance, and a research/clinically relevant biocide [68,78-81]. The cause of the elevated MIC were gene mutations. For P. aeruginosa, mutations of efflux pump genes such as MDR mexA-mexB-oprM and mexCmexD-oprJ were observed [82,83]. For E. coli, a mutation in the sugE gene located in the 94 regions of a chromosome that phenotypically inhibits a groEL mutation were observed [84,85]. For S. aureus, mutations of six different genes (i.e., qac $A$ / B, qacC (smr), $q a c G, q a c H$ and $q a c J)$ that contribute to the development of resistance to QAC were observed [86-89].

For disinfectants containing alcohols, aldehydes and iodine compounds, no relevant changes of MIC values were reported [90-94].

The MIC values for most commonly used biocides against clinically important bacteria are presented in Table 3. The bacteria considered resistant had an increased MIC at least two times the average MIC in the first column. 
Table 3. MIC of biocides and the expressed susceptibility/resistance of bacteria to disinfectants.

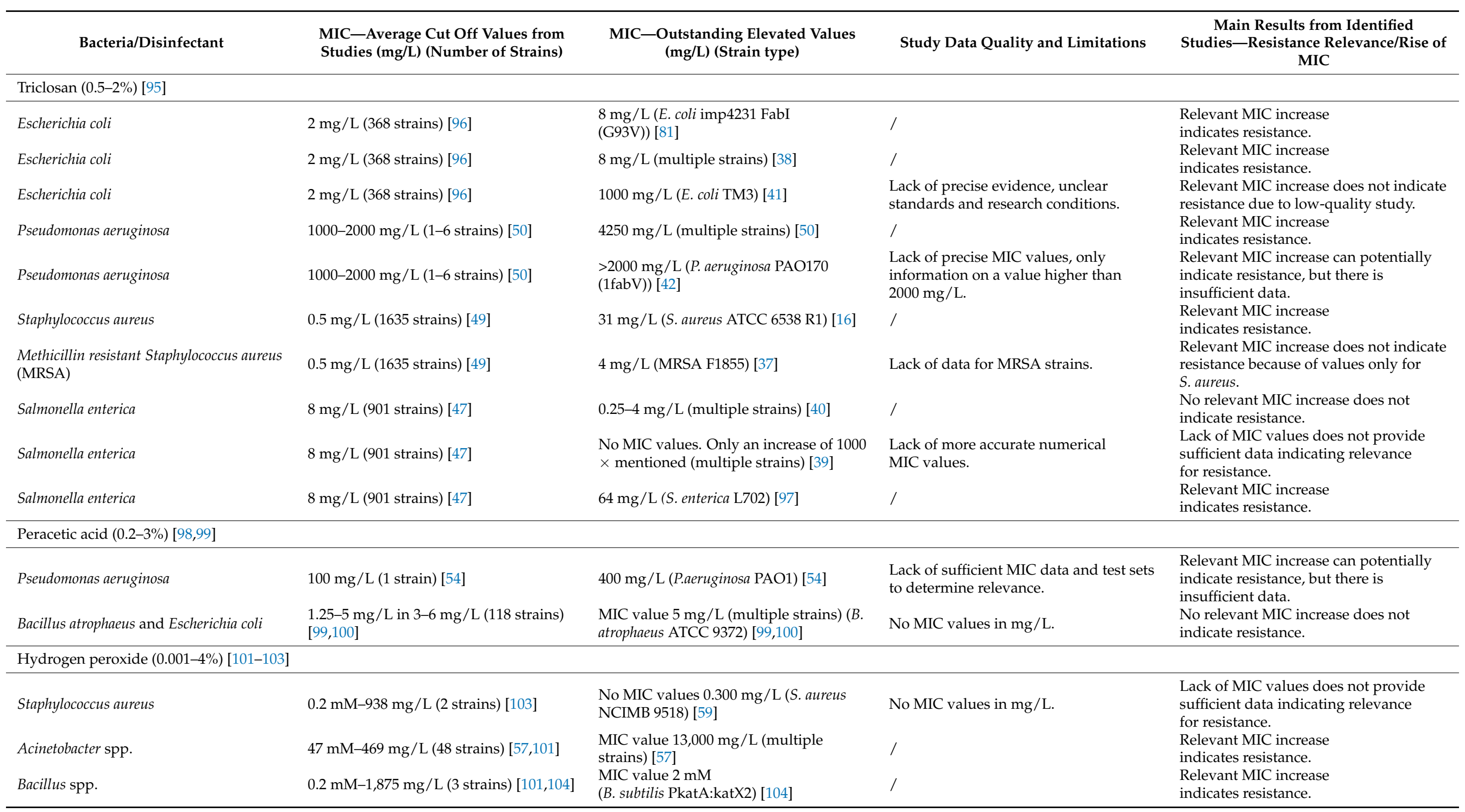


Table 3. Cont

\begin{tabular}{|c|c|c|c|c|}
\hline Bacteria/Disinfectant & $\begin{array}{l}\text { MIC-Average Cut Off Values from } \\
\text { Studies (mg/L) (Number of Strains) }\end{array}$ & $\begin{array}{l}\text { MIC-Outstanding Elevated Values } \\
\text { (mg/L) (Strain type) }\end{array}$ & Study Data Quality and Limitations & $\begin{array}{c}\text { Main Results from Identified } \\
\text { Studies-Resistance Relevance/Rise of } \\
\text { MIC }\end{array}$ \\
\hline \multicolumn{5}{|l|}{ Alcohols (70\%) [87,101] } \\
\hline $\begin{array}{l}\text { Enterococcus faecium } \\
\text { Staphylococcus aureus }\end{array}$ & $\begin{array}{l}\text { Od } 43,750 \mathrm{mg} / \mathrm{L} \text { do } 87,500 \mathrm{mg} / \mathrm{L} \\
\text { (7 strains) [101] }\end{array}$ & $\begin{array}{l}\text { No MIC values. The only number of } \\
\text { bacteria reduced in } \log ^{10}[91]\end{array}$ & No MIC values in mg/L. & $\begin{array}{l}\text { Lack of MIC values does not provide } \\
\text { sufficient data indicating relevance } \\
\text { for resistance. }\end{array}$ \\
\hline \multicolumn{5}{|l|}{ Aldehydes $(0.5-4.0 \%)[105,106]$} \\
\hline $\begin{array}{l}\text { Salmonella enterica } \\
\text { (Formaldehyde) }\end{array}$ & $0.3 \mathrm{mg} / \mathrm{L}$ (34 strains) [106] & $0.125 \mathrm{mg} / \mathrm{L}$ (multiple strains) [90] & / & \multirow{2}{*}{$\begin{array}{l}\text { No relevant MIC increase does not } \\
\text { indicate resistance. } \\
\text { Lack of MIC values does not provide } \\
\text { sufficient data indicating relevance } \\
\text { for resistance. }\end{array}$} \\
\hline $\begin{array}{l}\text { Pseudomonas aeruginosa } \\
\text { (Glutaraldehyde) }\end{array}$ & $3750 \mathrm{mg} / \mathrm{L}$ (1 strain) [105] & $\begin{array}{l}\text { No MIC values, only recognized increase } \\
\text { by } 3 \times(P . \text { aeruginosa ATCC 15442) [93] }\end{array}$ & $\begin{array}{l}\text { No sublethal MIC values and no MIC } \\
\text { measurement units described. }\end{array}$ & \\
\hline \multicolumn{5}{|l|}{ Chlorhexidine (0.5-4.0\%) [107] } \\
\hline Vancomycin-resistant Enterococcus (VRE) & $4-16 \mathrm{mg} / \mathrm{L}$ (5 strains) [1] & $8 \mathrm{mg} / \mathrm{L}$ (VRE VanA) [63] & / & \multirow{5}{*}{$\begin{array}{l}\text { No relevant MIC increase does not } \\
\text { indicate resistance. } \\
\text { Lack of MIC values does not provide } \\
\text { sufficient data indicating relevance } \\
\text { for resistance. } \\
\text { Relevant MIC increase } \\
\text { indicates resistance. } \\
\text { Relevant MIC increase } \\
\text { indicates resistance. } \\
\text { Relevant MIC increase } \\
\text { indicates resistance. } \\
\text { Relevant MIC increase } \\
\text { indicates resistance. }\end{array}$} \\
\hline $\begin{array}{l}\text { Methicillin resistant Staphylococcus aureus } \\
\text { (MRSA) }\end{array}$ & $8-128 \mathrm{mg} / \mathrm{L}$ (282 strains) [69] & $\begin{array}{l}\text { Only MIC }{ }^{50} \text { and } \mathrm{MIC}^{90} \text { values }<32 \mathrm{mg} / \mathrm{L} \\
\text { (multiple strains) [62] }\end{array}$ & No MIC values, only $\mathrm{MIC}^{50}$ and $\mathrm{MIC}^{90}$. & \\
\hline Enterococcus faecium & $32 \mathrm{mg} / \mathrm{L}$ (53 strains) [96] & $250 \mathrm{mg} / \mathrm{L}$ (multiple strains) [66] & / & \\
\hline Pseudomonas aeruginosa & $8-64 \mathrm{mg} / \mathrm{L}$ (70 strains) $[73,108]$ & $\begin{array}{l}70 \mathrm{mg} / \mathrm{L} \\
\text { (P. aeruginosa NCIMB 10421) [65] }\end{array}$ & / & \\
\hline Pseudomonas aeruginosa & $8-64 \mathrm{mg} / \mathrm{L}$ (70 strains) $[73,108]$ & $\begin{array}{l}1024 \mathrm{mg} / \mathrm{L} \\
\text { (P. aeruginosa NCTC 6749) [64] }\end{array}$ & / & \\
\hline \multicolumn{5}{|c|}{ Benzalkonium chloride and didecyldimonium chloride (0.01-5\%) [109] } \\
\hline $\begin{array}{l}\text { Pseudomonas spp. } \\
\text { (Benzalkonium chloride) }\end{array}$ & $4-512 \mathrm{mg} / \mathrm{L}$ (11 strains) $[77,110]$ & $>350 \mathrm{mg} / \mathrm{L}$ (P. aeruginosa PA-29) [80] & / & \multirow{5}{*}{$\begin{array}{l}\text { No relevant MIC increase does not } \\
\text { indicate resistance. } \\
\text { Relevant MIC increase can potentially } \\
\text { indicate resistance, but there is } \\
\text { insufficient data. } \\
\text { Relevant MIC increase } \\
\text { indicates resistance. } \\
\text { Relevant MIC increase can potentially } \\
\text { indicate resistance, although the MIC } \\
\text { rise is minimal. } \\
\text { Relevant MIC increase } \\
\text { indicates resistance. }\end{array}$} \\
\hline $\begin{array}{l}\text { Bacillus spp. } \\
\text { (Benzalkonium chloride) }\end{array}$ & $16 \mathrm{mg} / \mathrm{L}$ (1 strains) [96] & $\begin{array}{l}\text { 140-160 mg/L } \\
\text { (B. cereus ATCC 11778) [78] }\end{array}$ & $\begin{array}{l}\text { Disinfectant concentration and } \\
\text { disinfectant contact duration } \\
\text { not provided. }\end{array}$ & \\
\hline $\begin{array}{l}\text { Staphylococcus aureus } \\
\text { (Benzalkonium chloride) }\end{array}$ & $\begin{array}{l}16 \mathrm{mg} / \mathrm{L} \text { (1635 strains) [96] } \\
0.25-4 \mathrm{mg} / \mathrm{L} \text { (2 strains) [111] }\end{array}$ & $32 \mathrm{mg} / \mathrm{L}$ (multiple strains) [79] & 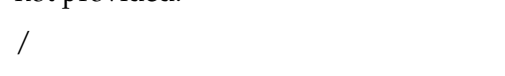 & \\
\hline $\begin{array}{l}\text { Listeria monocytogenes } \\
\text { (Benzalkonium chloride) }\end{array}$ & $4-10 \mathrm{mg} / \mathrm{L}$ (31 strains) $[111,112]$ & $14 \mathrm{mg} / \mathrm{L}$ (multiple strains) [81] & / & \\
\hline $\begin{array}{l}\text { Pseudomonas spp. } \\
\text { (Didecyldimonium chloride) }\end{array}$ & $5-40$ mg/L (11 strains) [113] & $120 \mathrm{mg} / \mathrm{L}$ (multiple strains) [1] & / & \\
\hline
\end{tabular}




\section{Discussion}

\subsection{Criteria to Identify Resistant Strains}

In order to understand resistance, there is an emphasis to distinguish between intrinsic and extrinsic resistance. Inherent resistance, known as natural resistance, is chromosomally encoded resistance, which determines the basic spectrum of effects of a disinfectant and the phenotypic resistance, e.g., biofilms. Extrinsic or acquired resistance develops through mutation by incorporating mobile genetic elements (horizontal gene transfer), transferable plasmids and other cell elements [114,115]. A clear distinction also needs to be made between phenotypic adaptation, which is reversible when exposure to the biocides ends, and acquired resistance, being genetically determined and usually stable [115]. When studying antibiotic resistance, the European Committee on Antimicrobial Susceptibility Testing has decided to: "define separate dividing points for the detection of bacteria with resistance mechanisms and the monitoring of resistance development using wild-type cut-off values (WCV) or epidemiological cut-off values (ECOFF or ECV) and the guidance of therapy via clinical breakpoints" [101,116]. As defined by the European Committee on Antimicrobial Susceptibility Testing, the ecological concept of antibiotic resistance states that ECOFFs are defined based on the normal distribution of MICs in a given bacterial species. Any isolate with a MIC above the epidemiological cut-off value (ECOFF), which is the upper limit of the normal distribution of the MIC for a given antimicrobial agent and a particular species, is considered resistant $[43,96]$.

In the case of studying biocide resistance, however, no limits have been set so far, and there are no clear criteria to determine whether a microbe is susceptible to the biocide or not. Therefore, we can use the average MIC values obtained from individual laboratory studies conducted under relatively similar conditions. The observed relevant increase in the MIC value can indicate a decreased susceptibility or even resistance. When interpreting the results, the in-use concentration of the disinfectants used must be considered since the in-use concentration may also be higher than the actual measured MIC values. In this case, we cannot talk about the resistance but only about a decreased susceptibility.

\subsection{Most Common Bacterial Mechanisms to Develop Resistance against Disinfectants}

Bacteria control and overcome the effect of disinfectants in different ways (Table 4), such as restricted permeability of the cell wall, the expression of efflux systems, enzymatic degradation, changes in target sites, and the formation of biofilms [23,117]. Changes in cell surface hydrophobicity, ultrastructure, protein composition, and fatty acid modifications appear to occur $[118,119]$. For example, inactivation of the lipooligosaccharide biosynthesis genes causes resistance in A. baumannii [120]. Modifying the outer membrane proteins and an increased expression of cellular structures may increase the sensitivity to disinfectants $[118,119,121]$. Impermeability of the outer membrane occurs because of the lipopolysaccharide component, which increases the penetration of disinfectants and affects the size and expression of pores, thereby preventing entry and affecting sensitivity [122]. The hydrophilic porin channels on the outer membrane regulate the passage of solutes and are a significant barrier to hydrophilic substance penetration [123]. They also have a negative charge, which can cause the disinfectant molecules to bounce away from the bacterial cell.

Bacteria can also grow as biofilms, endospores, and within cellular macrophages. In most natural habitats, microorganisms grow and survive as associated biofilms [124]. Monocultures of several different species or mixed phenotypes of a particular species can form biofilms. It is a community of nonmobile microorganisms that are irreversibly attached to a surface and inserted into a polymeric extracellular matrix. The insensitivity of biofilms to disinfectants is due to altered microbial growth rates, which can be attributed to nutrient depletion in the biofilm, and disinfectant binding to the biofilm, which is neutralized or degraded [35]. Such an organization may moderate the concentration of antimicrobial disinfectants and antibiotics to which deeper biofilm cells are exposed. Such 
cells accidentally grow slowly, starve, and express stress phenotypes, including regulating efflux pumps and flushing out disinfectants [125].

Slightly less effective mechanisms involve the enzymatic degradation or inactivation of disinfectants when concentrations of agents, such as formaldehyde, chlorhexidine, and quaternary ammonium compounds, are lower than those used in clinical trials practice [126]. The exposure of bacteria to minimal inhibitory concentrations of disinfectants results in the induced expression of neutralizing enzymes, which is crucial for the biodegradation of disinfectants [127]. Examples of the neutralization of disinfectants have been given in several species of bacteria, for example, Pseudomonas fluorescens TN4 isolated from sludge was able to degrade DDAC, which belongs to the group of quaternary ammonium compounds. The isolate was also able to degrade other QACs by the N-dealkylation process [128].

One major cause of bacterial resistance is the active transport of substances to the cell exterior, the so-called efflux with proteins. Efflux pump mechanisms perform essential physiological functions [97]. Although existing in all living cells, those found in bacterial and mammalian cells are especially important for clinicians and pharmacologists since they constitute an important cause of antimicrobial resistance. Multidrug Resistance (MDR) efflux pumps present an ongoing research topic in antibiotic resistance and are also responsible for disinfectant resistance mechanisms [129]. One of the fundamental mechanisms of action is the efflux pump's influence and the modulation of its genes. These efflux systems existed in bacteria long before the use of disinfectants and antibiotics in humans to treat infections. The mechanism involves the secretion of toxic compounds through a bacterial cell wall with a membrane-bound protein composed of at least three components. The increased expression of these pumps can raise the minimum inhibitory concentration to a high level, resulting in resistance to disinfectants [130] and greater sensitivity and crossresistance to antibiotics [40]. Research data show that pump expression reduces the efficacy of various classes of disinfectants, including chlorhexidine digluconate, hydrogen peroxide, benzalkonium chloride, chloroxylenol, iodine compounds, triclosan, quaternary ammonium compounds, phenolic parabens and intercalates [131,132]. Among the best-studied systems of genes that regulate the secretion of biocides are mexAB-oprM, mexCD-oprJ and mexEF-oprN in P. aeruginosa [133], acrAB-tolC, acrEF-tolC and emrE in E. coli [134], smeDEF in bacteria Stenotrophomonas maltophilia [135], and nor A and mepA in S. aureus. In the highly resistant nosocomial bacterium $A$. baumannii, the efflux activity is regulated by the quacA and quacB genes $[57,77,136]$. Bacteria use the same pumps to remove antibiotics and biocides. Thus, they can select antibiotic-resistant mutants that over-regulate such pumps [137].

Another important factor contributing to the development of disinfectant resistance is the mode of action of disinfectants. Biocides have a broader spectrum of activity and may have multiple targets, while antibiotics tend to have specific intracellular targets [29]. However, in the case of biocides with a particular antimicrobial mechanism (e.g., quaternary ammonium compounds-QAC's), the development of antimicrobial resistance against disinfectants, and cross-resistance to antibiotics, are especially well documented [138].

Table 4. Disinfectant and bacterial mechanisms for the most commonly used disinfectants.

\begin{tabular}{|c|c|c|c|c|c|}
\hline $\begin{array}{l}\text { Disinfectant } \\
\text { Category }\end{array}$ & $\begin{array}{c}\text { Active } \\
\text { Ingredient }\end{array}$ & $\begin{array}{l}\text { Use in Clinical } \\
\text { Setting }\end{array}$ & Disinfectant Working Mechanism & $\begin{array}{l}\text { Bacterial Adaptation to } \\
\text { Disinfectant }\end{array}$ & Ref. \\
\hline Alcohol & $\begin{array}{l}\text { Ethic Alcohol } \\
\text { (Ethanol) }\end{array}$ & $\begin{array}{l}\text { 70-95\% Ethanol } \\
\text { solution }\end{array}$ & $\begin{array}{c}\text { Denaturation of bacterial membrane } \\
\text { proteins and dissolving lipid } \\
\text { components such as antiparallel } \beta \\
\text { and } 3_{10} \text { helical turns of proteins, C-H } \\
\text { deformations in lipids, inhibition of } \\
\text { nutrient transport via } \\
\text { membrane-bound ATPases, alteration } \\
\text { of membrane pH and } \\
\text { membrane potential. }\end{array}$ & $\begin{array}{l}\text { Horizontal gene transfer, } \\
\text { transformation and transduction } \\
\text { and core genome mutations in } \\
\text { the chromosome nucleotide } \\
\text { position on the rpoB gene } \beta \\
\text { subunit of RNA polymerase. }\end{array}$ & $\begin{array}{c}\text { Alcohol working } \\
\text { mechanism: }[6,139-141] \\
\text { Alcohol adaptation: } \\
{[91,142]}\end{array}$ \\
\hline
\end{tabular}


Table 4. Cont

\begin{tabular}{|c|c|c|c|c|c|}
\hline $\begin{array}{l}\text { Disinfectant } \\
\text { Category }\end{array}$ & $\begin{array}{c}\text { Active } \\
\text { Ingredient }\end{array}$ & $\begin{array}{l}\text { Use in Clinical } \\
\text { Setting }\end{array}$ & Disinfectant Working Mechanism & $\begin{array}{l}\text { Bacterial Adaptation to } \\
\text { Disinfectant }\end{array}$ & Ref. \\
\hline Aldehydes & Formaldehyde & $\begin{array}{l}5 \% \text { Formaldehyde } \\
\text { solution }\end{array}$ & $\begin{array}{l}\text { Cross-linking of protein's free amino } \\
\text { groups and inhibition of transport } \\
\text { processes, RNA, and DNA. }\end{array}$ & $\begin{array}{l}\text { Inactivation of formaldehyde } \\
\text { through a metabolic system } \\
\text { dependent on pterin cofactors, } \\
\text { sugar phosphates, and those } \\
\text { dependent on glutathione. Three } \\
\text { separate enzymes catalyze } \\
\text { successive stages of } \\
\text { formaldehyde oxidation to } \mathrm{CO}_{2} \text {. } \\
\text { These are the enzyme Gfa, } \\
\text { alcohol dehydrogenase, and } \\
\text { thioesterase. The specifically } \\
\text { transmissible plasmid adhC gene } \\
\text { encodes a glutathione-dependent } \\
\text { formaldehyde dehydrogenase } \\
\text { that causes inactivation. }\end{array}$ & $\begin{array}{c}\text { Formaldehyde working } \\
\text { mechanism: }[3,29] \\
\text { Formaldehyde adaptation: } \\
{[143-145]}\end{array}$ \\
\hline Biguanides & $\begin{array}{l}\text { Chlorhexidine } \\
\text { (gluconate/ } \\
\text { diacetate) }\end{array}$ & $\begin{array}{l}0.5 \% \text { Alcohol } \\
\text { solution }(70 \%)\end{array}$ & $\begin{array}{l}\text { Inhibition of cytoplasmic membrane } \\
\text { function and membrane-bound } \\
\text { enzymes and leakage of intracellular } \\
\text { components; inhibitor of both } \\
\text { membrane-bound and soluble ATPase } \\
\text { as well as of net K+ uptake, also } \\
\text { collapses the membrane potential and } \\
\text { has the potential for } \\
\text { ATPase inactivation. }\end{array}$ & $\begin{array}{l}\text { Induced gene expression of efflux } \\
\text { pumps with upregulation and } \\
\text { downregulation of coding genes } \\
\text { (for an MFS transporter and } \\
\text { HlyD-like periplasmic adaptor } \\
\text { protein), active ingredient } \\
\text { inactivation and alteration of the } \\
\text { cell wall, increase in cell envelope } \\
\text { components such as } \\
\text { lipopolysaccharide or } \\
\text { phospholipid caused by } \\
\text { progressive mutations. }\end{array}$ & $\begin{array}{c}\text { Chlorhexidine working } \\
\text { mechanism: }[29,33] \\
\text { Chlorhexidine adaptation: } \\
{[29,33,43,65,146]}\end{array}$ \\
\hline Bisphenol & Triclosan & & $\begin{array}{c}\text { Inhibition of enoyl-acyl carrier protein } \\
(\mathrm{ACP}) \text { reductase (FabI enzyme) in } E \text {. } \\
\text { coli, P. aeruginosa, S. aureus and its } \\
\text { homologue InhA in M. smegmatis, } \\
\text { M. tuberculosis. }\end{array}$ & $\begin{array}{l}\text { Target mutations, increased } \\
\text { target expression (overexpressed } \\
\text { genes } m u f A 1 \text { and } m u f M \text { ), active } \\
\text { cell excretion, enzyme } \\
\text { inactivation/ degradation. } \\
\text { Increased concentration of } \\
\text { branched chain fatty acids in the } \\
\text { cell membrane occurs and } \\
\text { multiple amino acids are changed } \\
\text { in the } f a b I \text { gene along with an } \\
\text { increased concentration of the } \\
\text { FabI protein through } \\
\text { heterologous duplication and } \\
\text { increased activity of } \\
\text { ENR isoenzymes. }\end{array}$ & $\begin{array}{c}\text { Triclosan working } \\
\text { mechanism: } \\
{[19,39,134,147,148]} \\
\text { Triclosan adaptation: } \\
{[30,149-151]}\end{array}$ \\
\hline $\begin{array}{l}\text { Halogen } \\
\text { releasing } \\
\text { agents }\end{array}$ & $\begin{array}{l}\text { Povidone- } \\
\text { Iodine }\end{array}$ & $\begin{array}{l}1-10 \% \text { Iodine } \\
\text { solution }\end{array}$ & $\begin{array}{c}\text { Intracytoplasmic protein oxidation } \\
\text { (cysteine and methionine), nucleotide } \\
\text { and fatty acid function disruption, } \\
\text { inhibition of production and release of } \\
\text { bacterial exotoxins such as } \\
\alpha \text {-hemolysin, phospholipase C and } \\
\text { enzymes such as elastase and } \\
\beta \text {-glucuronide. }\end{array}$ & $\begin{array}{l}\text { Formation of a biofilm and } \\
\text { thickening of the cell wall. }\end{array}$ & $\begin{array}{c}\text { Halogen releasing agents } \\
\text { working mechanism: } \\
\text { [29,152,153] } \\
\text { Halogen releasing agents } \\
\text { adaptation: }[153,154]\end{array}$ \\
\hline Peroxygens & $\begin{array}{l}\text { Hydrogen } \\
\text { Peroxide }\end{array}$ & $\begin{array}{c}3-6 \% \text { Hydrogen } \\
\text { Peroxide }\end{array}$ & $\begin{array}{l}\mathrm{H}_{2} \mathrm{O}_{2} \text { acts as an oxidant by producing } \\
\text { hydroxyl or ferryl free radicals which } \\
\text { disrupt the function of lipids, } \\
\text { proteins-sulfhydryl (SH) and sulfur } \\
\text { (SS) bonds and DNA. }\end{array}$ & $\begin{array}{l}\text { Gene kat } A \text { role of catalase, and } \\
\text { peroxidase enzymes which } \\
\text { neutralize } \mathrm{H}_{2} \mathrm{O}_{2} \text {. Bacterial cells } \\
\text { form thick biofilm formations. }\end{array}$ & $\begin{array}{l}\text { Hydrogen peroxide agents } \\
\text { working mechanism: } \\
\text { [29,155] } \\
\text { Hydrogen peroxide agents } \\
\text { adaptation: [155-157] }\end{array}$ \\
\hline $\begin{array}{l}\text { Quaternary } \\
\text { Ammonium } \\
\text { Compounds }\end{array}$ & $\begin{array}{l}\text { Benzalkonium } \\
\text { Chloride }\end{array}$ & $\begin{array}{l}0.01-5 \% \\
\text { Benzalkonium } \\
\text { chloride }\end{array}$ & $\begin{array}{l}\text { Cationic amphiphilic properties } \\
\text { destabilize the pathogen's surface by } \\
\text { forming electrostatic interactions with } \\
\text { negatively charged components. } \\
\text { Cytoplasmic membrane damage of } \\
\text { phospholipid components occurs, } \\
\text { distortion and protoplast lysis occur } \\
\text { under osmotic stress. Leakage of low } \\
\text { molecular weight components and } \\
\text { eventual cell wall lysis. }\end{array}$ & $\begin{array}{l}\text { Downregulation of membrane } \\
\text { porins, overexpression or } \\
\text { modification of efflux pumps } \\
\text { (Mrdl EmrE MdfA) with } \\
\text { mutations of the Mex system, } \\
\text { horizontal gene transfer of } \\
\text { transposon elements (Tn6188) } \\
\text { and stress factors, biofilm } \\
\text { formation, and biodegradation } \\
\text { by dealkylation. }\end{array}$ & $\begin{array}{l}\text { Benzalkonium chloride } \\
\text { releasing agents working } \\
\text { mechanism: }[29,78,158] \\
\text { Benzalkonium chloride } \\
\text { releasing agents } \\
\text { adaptation: }[82,159]\end{array}$ \\
\hline
\end{tabular}

\section{Conclusions}

Antimicrobial resistance in healthcare facilities has been occurring and regularly increasing over the last ten years. Growing evidence from in vitro studies has shown that bacteria have a tremendous ability to respond to chemical stress caused by biocides by several different mechanisms [160]. The main reason for emerging resistance is attributed mainly to the overuse, abuse and misuse of disinfectants [160-162]. Relevant increases in MIC concentrations, changes at the genetic level, and clearly altered mechanisms were 
observed in studies of several bacterial species in the presence of disinfectants. Through the most relevant of the reviewed articles, we can define the results for disinfectants based on triclosan and chlorhexidine, where the critical deviation of the MIC was observed in multiple studies.

Given the ongoing problems with multiple antibiotic resistance in clinically important bacteria strains and the potential for increased resistance to disinfectants, the use of which is rising in the community, it is clear that the prudent use of available and effective antimicrobials is needed. It is essential to develop and adopt strategies to control disinfectant resistance, for which the following factors will make a significant contribution. To solve the disinfectant resistance problem, it is essential to comprehensively summarize the disinfectant resistance mechanisms and to understand the resistance influencing factors [163]. It is also necessary to establish ECOFF values for biocides, without which any research is challenging and, to some extent, inaccurate. Harmonized methods for biocide susceptibility testing need to be developed.

Further studies are needed to establish a link between disinfectant exposure and resistance development, as many studies in clinical or external settings are currently limited. The rotation of disinfectants, where one disinfectant should be replaced by another having a different mechanism of action, is recommended [164]. The same types of disinfectants are used both in healthcare institutions and among the general population; therefore, their prudent use and consumption, as we know in the case of antibiotics, are complicated to control. Since selective pressure caused by disinfectants is exerted on both commensal and pathogenic bacteria $[165,166]$, monitoring for resistant genes in nonpathogenic or commensal bacteria would make sense. Health-related infections acquired in the community need to be researched annually. More attention should be paid to the correct use of disinfectants by the general public, although supervising the proper use of disinfectants among the general population is very difficult to implement.

The risks and benefits of using disinfectants in the environment need to be weighed to determine whether additional precautions are required to guide the development and use of disinfectants [167]. If bacterial resistance increases and develops against many regularly used disinfectants in clinical and industrial settings, overuse in reflection of the COVID-19 pandemic could place an additional burden on global public health [168].

Author Contributions: U.R.: substantial contributions to conception and design, data acquisition, analysis and interpretation; drafting the article and revising it critically for important intellectual content; final approval of the version to be published. M.P.: substantial contributions to conception and design, data acquisition, analysis and interpretation; drafting the article. S.K.: substantial contributions to conception and design, critically revising the article. D.D.: substantial contributions to conception and design, data acquisition, analysis and interpretation; drafting the article and revising it critically for important intellectual content; final approval of the version to be published. S.Š.T.: substantial contributions to conception and design; final approval of the version to be published. All authors have read and agreed to the published version of the manuscript.

Funding: We are very grateful to Sanlas Holding $\mathrm{GmbH}$, Austria who acted as a co-financer of the project. The research was also financially supported by the national research program (P2-0118).

Institutional Review Board Statement: Not applicable.

Informed Consent Statement: Not applicable.

Data Availability Statement: Not applicable.

Conflicts of Interest: The authors declare no conflict of interest. The funders had no role in the design of the study; in the collection, analyses, or interpretation of data; in the writing of the manuscript, or in the decision to publish the results. 


\section{References}

1. ECHA. Biocidal Products Regulation-Product Types. Available online: https://echa.europa.eu/regulations/biocidal-productsregulation/product-types (accessed on 10 February 2021).

2. Maillard, J.-Y. Bacterial resistance to biocides in the healthcare environment: Should it be of genuine concern? J. Hosp. Infect. 2007, 65, 60-72. [CrossRef]

3. Maillard, J.Y. Bacterial target sites for biocide action. J. Appl. Microbiol. 2002, 92, 16S-27S. [CrossRef] [PubMed]

4. Pohl, K.; Dulio, V.; Botta, F.; Schwarzbauer, J.; Rüdel, H. Environmental monitoring of biocides in Europe: Compartment-specific strategies-Workshop report. In Proceedings of the Environmental Monitoring of Biocides in Europe: Compartment-Specific strategies, Berlin, Germany, 25-26 June 2015.

5. $\quad$ Dumas, O.; Wiley, A.S.; Henneberger, P.K.; Speizer, F.E.; Zock, J.P.; Varraso, R.; Le Moual, N.; Boggs, K.M.; Camargo, C.A., Jr. Determinants of disinfectant use among nurses in US healthcare facilities. Am. J. Ind. Med. 2017, 60, 131-140. [CrossRef] [PubMed]

6. Rutala, W.A.; Weber, D.J. Disinfection and sterilization in health care facilities: What clinicians need to know. Clin. Infect. Dis. 2004, 39, 702-709. [CrossRef]

7. Hahn, S.; Schneider, K.; Gartiser, S.; Heger, W.; Mangelsdorf, I. Consumer exposure to biocides-identification of relevant sources and evaluation of possible health effects. Environ. Health 2010, 9, 7. [CrossRef]

8. Sim, S.; Lee, J.; Uhm, Y.; Kim, S.; Han, E.J.; Choi, K.; Choi, J.; Ban, Q.-m.; Cho, T.; Kim, A.Y. Korean consumers' awareness of the risks of chemicals in daily consumer products. Environ. Sci. Eur. 2019, 31, 97. [CrossRef]

9. Staniford, L.J.; Schmidtke, K.A. A systematic review of hand-hygiene and environmental-disinfection interventions in settings with children. BMC Public Health 2020, 20, 195. [CrossRef]

10. Beyth, N.; Houri-Haddad, Y.; Domb, A.; Khan, W.; Hazan, R. Alternative antimicrobial approach: Nano-antimicrobial materials. Evid.-Based Complementary Altern. Med. 2015, 2015, 246012. [CrossRef]

11. Czaplewski, L.; Bax, R.; Clokie, M.; Dawson, M.; Fairhead, H.; Fischetti, V.A.; Foster, S.; Gilmore, B.F.; Hancock, R.E.; Harper, D. Alternatives to antibiotics-A pipeline portfolio review. Lancet Infect. Dis. 2016, 16, 239-251. [CrossRef]

12. Rios, A.C.; Moutinho, C.G.; Pinto, F.C.; Del Fiol, F.S.; Jozala, A.; Chaud, M.V.; Vila, M.M.; Teixeira, J.A.; Balcão, V.M. Alternatives to overcoming bacterial resistances: State-of-the-art. Microbiol. Res. 2016, 191, 51-80. [CrossRef]

13. Sakudo, A.; Yagyu, Y.; Onodera, T. Disinfection and sterilization using plasma technology: Fundamentals and future perspectives for biological applications. Int. J. Mol. Sci. 2019, 20, 5216. [CrossRef]

14. Gebel, J.; Exner, M.; French, G.; Chartier, Y.; Christiansen, B.; Gemein, S.; Goroncy-Bermes, P.; Hartemann, P.; Heudorf, U.; Kramer, A. The role of surface disinfection in infection prevention. GMS Hyg. Infect. Control. 2013, 8, Doc10. [CrossRef]

15. Gomes, I.; Malheiro, J.; Mergulhão, F.; Maillard, J.-Y.; Simões, M. Comparison of the efficacy of natural-based and synthetic biocides to disinfect silicone and stainless steel surfaces. Pathog. Dis. 2016, 74, ftw014. [CrossRef] [PubMed]

16. Forbes, S.; Latimer, J.; Bazaid, A.; McBain, A.J. Altered competitive fitness, antimicrobial susceptibility, and cellular morphology in a triclosan-induced small-colony variant of Staphylococcus aureus. Antimicrob. Agents Chemother. 2015, 59, 4809-4816. [CrossRef]

17. Russell, A. Biocide use and antibiotic resistance: The relevance of laboratory findings to clinical and environmental situations. Lancet Infect. Dis. 2003, 3, 794-803. [CrossRef]

18. Wieland, N.; Boss, J.; Lettmann, S.; Fritz, B.; Schwaiger, K.; Bauer, J.; Hölzel, C. Susceptibility to disinfectants in antimicrobialresistant and-susceptible isolates of Escherichia coli, Enterococcus faecalis and Enterococcus faecium from poultry-ESBL/AmpCphenotype of $E$. coli is not associated with resistance to a quaternary ammonium compound, DDAC. J. Appl. Microbiol. 2017, 122, 1508-1517.

19. Yazdankhah, S.P.; Scheie, A.A.; Høiby, E.A.; Lunestad, B.-T.; Heir, E.; Fotland, T.Ø.; Naterstad, K.; Kruse, H. Triclosan and antimicrobial resistance in bacteria: An overview. Microb. Drug Resist. 2006, 12, 83-90. [CrossRef]

20. European Commission. Assessment of the Antibiotic Resistance Effects of Biocides; European Commission: Brussels, Belgium, 2009.

21. European Commission. Biocides Overview. Available online: https://ec.europa.eu/health/biocides/overview_en (accessed on 10 February 2021).

22. Babeluk, R.; Jutz, S.; Mertlitz, S.; Matiasek, J.; Klaus, C. Hand hygiene-evaluation of three disinfectant hand sanitizers in a community setting. PLoS ONE 2014, 9, e111969. [CrossRef] [PubMed]

23. Chapman, J.S. Biocide resistance mechanisms. Int. Biodeterior. Biodegrad. 2003, 51, 133-138. [CrossRef]

24. Goudarzi, M.; Navidinia, M. Overview perspective of bacterial strategies of resistance to biocides and antibiotics. Arch. Clin. Infect. Dis. 2019, 14, e65744.

25. Romero, J.L.; Grande Burgos, M.J.; Pérez-Pulido, R.; Gálvez, A.; Lucas, R. Resistance to antibiotics, biocides, preservatives and metals in bacteria isolated from seafoods: Co-selection of strains resistant or tolerant to different classes of compounds. Front. Microbiol. 2017, 8, 1650. [CrossRef]

26. Weber, D.J.; Rutala, W.A. Use of germicides in the home and the healthcare setting: Is there a relationship between germicide use and antibiotic resistance? Infect. Control. Hosp. Epidemiol. 2006, 27, 1107-1119. [CrossRef]

27. Jiang, S.; Zeng, J.; Zhou, X.; Li, Y. Drug resistance and gene transfer mechanisms in respiratory/oral bacteria. J. Dent. Res. 2018, 97, 1092-1099. [CrossRef]

28. Poole, K. Mechanisms of bacterial biocide and antibiotic resistance. J. Appl. Microbiol. 2002, 92, 55S-64S. [CrossRef] [PubMed]

29. McDonnell, G.; Russell, A.D. Antiseptics and disinfectants: Activity, action, and resistance. Clin. Microbiol. Rev. 1999, 12, 147-179. [CrossRef] [PubMed] 
30. Carey, D.E.; McNamara, P.J. The impact of triclosan on the spread of antibiotic resistance in the environment. Front. Microbiol. 2015, 5, 780. [CrossRef] [PubMed]

31. Kampf, G. Biocidal agents used for disinfection can enhance antibiotic resistance in gram-negative species. Antibiotics 2018, 7, 110. [CrossRef] [PubMed]

32. Wand, M.E.; Bock, L.J.; Bonney, L.C.; Sutton, J.M. Mechanisms of increased resistance to chlorhexidine and cross-resistance to colistin following exposure of Klebsiella pneumoniae clinical isolates to chlorhexidine. Antimicrob. Agents Chemother. 2017, 61, e01162-16. [CrossRef]

33. Cieplik, F.; Jakubovics, N.S.; Buchalla, W.; Maisch, T.; Hellwig, E.; Al-Ahmad, A. Resistance toward chlorhexidine in oral bacteria-Is there cause for concern? Front. Microbiol. 2019, 10, 587. [CrossRef] [PubMed]

34. Walsh, S.E.; Maillard, J.-Y.; Russell, A.; Catrenich, C.; Charbonneau, D.; Bartolo, R. Development of bacterial resistance to several biocides and effects on antibiotic susceptibility. J. Hosp. Infect. 2003, 55, 98-107. [CrossRef]

35. Gilbert, P.; Allison, D.; McBain, A. Biofilms in vitro and in vivo: Do singular mechanisms imply cross-resistance? J. Appl. Microbiol. 2002, 92, 98S-110S. [CrossRef]

36. Moher, D.; Liberati, A.; Tetzlaff, J.; Altman, D.G.; Group, P. Preferred reporting items for systematic reviews and meta-analyses: The PRISMA statement. PLoS Med. 2009, 6, e1000097. [CrossRef]

37. Bayston, R.; Ashraf, W.; Smith, T. Triclosan resistance in methicillin-resistant Staphylococcus aureus expressed as small colony variants: A novel mode of evasion of susceptibility to antiseptics. J. Antimicrob. Chemother. 2007, 59, 848-853. [CrossRef] [PubMed]

38. Cameron, A.; Barbieri, R.; Read, R.; Church, D.; Adator, E.H.; Zaheer, R.; McAllister, T.A. Functional screening for triclosan resistance in a wastewater metagenome and isolates of Escherichia coli and Enterococcus spp. from a large Canadian healthcare region. PLoS ONE 2019, 14, e0211144. [CrossRef]

39. Condell, O.; Sheridan, A.; Power, K.; Bonilla-Santiago, R.; Sergeant, K.; Renaut, J.; Burgess, C.; Fanning, S.; Nally, J. Comparative proteomic analysis of Salmonella tolerance to the biocide active agent triclosan. J. Proteom. 2012, 75, 4505-4519. [CrossRef]

40. Copitch, J.L.; Whitehead, R.N.; Webber, M.A. Prevalence of decreased susceptibility to triclosan in Salmonella enterica isolates from animals and humans and association with multiple drug resistance. Int. J. Antimicrob. Agents 2010, 36, 247-251. [CrossRef]

41. Cottell, A.; Denyer, S.; Hanlon, G.; Ochs, D.; Maillard, J.-Y. Triclosan-tolerant bacteria: Changes in susceptibility to antibiotics. J. Hosp. Infect. 2009, 72, 71-76. [CrossRef]

42. Huang, Y.-H.; Lin, J.-S.; Ma, J.-C.; Wang, H.-H. Functional characterization of triclosan-resistant enoyl-acyl-carrier protein reductase (FabV) in Pseudomonas aeruginosa. Front. Microbiol. 2016, 7, 1903. [CrossRef]

43. Levy, S. Active efflux, a common mechanism for biocide and antibiotic resistance. J. Appl. Microbiol. 2002, 92, 65S-71S. [CrossRef]

44. Webber, M.A.; Randall, L.P.; Cooles, S.; Woodward, M.J.; Piddock, L.J. Triclosan resistance in Salmonella enterica serovar Typhimurium. J. Antimicrob. Chemother. 2008, 62, 83-91. [CrossRef]

45. Yu, B.J.; Kim, J.A.; Pan, J.-G. Signature gene expression profile of triclosan-resistant Escherichia coli. J. Antimicrob. Chemother. 2010, 65, 1171-1177. [CrossRef]

46. Williams, P.; Cámara, M. Quorum sensing and environmental adaptation in Pseudomonas aeruginosa: A tale of regulatory networks and multifunctional signal molecules. Curr. Opin. Microbiol. 2009, 12, 182-191. [CrossRef]

47. Ellison, M.L.; Roberts, A.L.; Champlin, F.R. Susceptibility of compound 48/80-sensitized Pseudomonas aeruginosa to the hydrophobic biocide triclosan. FEMS Microbiol. Lett. 2007, 269, 295-300. [CrossRef] [PubMed]

48. Zhu, L.; Lin, J.; Ma, J.; Cronan, J.E.; Wang, H. Triclosan resistance of Pseudomonas aeruginosa PAO1 is due to FabV, a triclosanresistant enoyl-acyl carrier protein reductase. Antimicrob. Agents Chemother. 2010, 54, 689-698. [CrossRef]

49. Chuanchuen, R.; Karkhoff-Schweizer, R.R.; Schweizer, H.P. High-level triclosan resistance in Pseudomonas aeruginosa is solely a result of efflux. Am. J. Infect. Control. 2003, 31, 124-127. [CrossRef]

50. D'Arezzo, S.; Lanini, S.; Puro, V.; Ippolito, G.; Visca, P. High-level tolerance to triclosan may play a role in Pseudomonas aeruginosa antibiotic resistance in immunocompromised hosts: Evidence from outbreak investigation. BMC Res. Notes $2012,5,43$. [CrossRef]

51. Ciusa, M.L.; Furi, L.; Knight, D.; Decorosi, F.; Fondi, M.; Raggi, C.; Coelho, J.R.; Aragones, L.; Moce, L.; Visa, P.; et al. A novel resistance mechanism to triclosan that suggests horizontal gene transfer and demonstrates a potential selective pressure for reduced biocide susceptibility in clinical strains of Staphylococcus aureus. Int. J. Antimicrob. Agents 2012, 40, 210-220. [CrossRef]

52. Giuliano, C.A.; Rybak, M.J. Efficacy of triclosan as an antimicrobial hand soap and its potential impact on antimicrobial resistance: A focused review. Pharmacotherapy 2015, 35, 328-336. [CrossRef]

53. Nielsen, L.N.; Larsen, M.H.; Skovgaard, S.; Kastbjerg, V.; Westh, H.; Gram, L.; Ingmer, H. Staphylococcus aureus but not Listeria monocytogenes adapt to triclosan and adaptation correlates with increased fabI expression and agr deficiency. BMC Microbiol. 2013, 13, 177. [CrossRef]

54. Spoering, A.L.; Lewis, K. Biofilms and planktonic cells of Pseudomonas aeruginosa have similar resistance to killing by antimicrobials. J. Bacteriol. 2001, 183, 6746-6751. [CrossRef]

55. Van der Veen, S.; Abee, T. Mixed species biofilms of Listeria monocytogenes and Lactobacillus plantarum show enhanced resistance to benzalkonium chloride and peracetic acid. Int. J. Food Microbiol. 2011, 144, 421-431. [CrossRef]

56. Turolla, A.; Sabatino, R.; Fontaneto, D.; Eckert, E.M.; Colinas, N.; Corno, G.; Citterio, B.; Biavasco, F.; Antonelli, M.; Mauro, A. Defence strategies and antibiotic resistance gene abundance in enterococci under stress by exposure to low doses of peracetic acid. Chemosphere 2017, 185, 480-488. [CrossRef] 
57. Lin, F.; Xu, Y.; Chang, Y.; Liu, C.; Jia, X.; Ling, B. Molecular characterization of reduced susceptibility to biocides in clinical isolates of Acinetobacter baumannii. Front. Microbiol. 2017, 8, 1836. [CrossRef]

58. Pericone, C.D.; Overweg, K.; Hermans, P.W.; Weiser, J.N. Inhibitory and bactericidal effects of hydrogen peroxide production by Streptococcus pneumoniae on other inhabitants of the upper respiratory tract. Infect. Immun. 2000, 68, 3990-3997. [CrossRef]

59. Wesgate, R.; Grasha, P.; Maillard, J.-Y. Use of a predictive protocol to measure the antimicrobial resistance risks associated with biocidal product usage. Am. J. Infect. Control. 2016, 44, 458-464. [CrossRef]

60. Oogai, Y.; Kawada-Matsuo, M.; Komatsuzawa, H. Staphylococcus aureus SrrAB affects susceptibility to hydrogen peroxide and co-existence with Streptococcus sanguinis. PLoS ONE 2016, 11, e0159768. [CrossRef]

61. Pesakhov, S.; Benisty, R.; Sikron, N.; Cohen, Z.; Gomelsky, P.; Khozin-Goldberg, I.; Dagan, R.; Porat, N. Effect of hydrogen peroxide production and the Fenton reaction on membrane composition of Streptococcus pneumoniae. Biochim. Biophys. Acta (BBA) Biomembr. 2007, 1768, 590-597. [CrossRef]

62. Akinkunmi, E.O.; Lamikanra, A. Susceptibility of community associated methicillin resistant Staphylococcus aureus isolated from faeces to antiseptics. J. Infect. Dev. Ctries. 2011, 6, 317-323. [CrossRef]

63. Braga, T.M.; Pomba, C.; Lopes, M.F.S. High-level vancomycin resistant Enterococcus faecium related to humans and pigs found in dust from pig breeding facilities. Vet. Microbiol. 2013, 161, 344-349. [CrossRef]

64. Kampf, G. Adaptive bacterial response to low level chlorhexidine exposure and its implications for hand hygiene. Microb. Cell 2019, 6, 307. [CrossRef]

65. Thomas, L.; Maillard, J.-Y.; Lambert, R.; Russell, A. Development of resistance to chlorhexidine diacetate in Pseudomonas aeruginosa and the effect of a'residual'concentration. J. Hosp. Infect. 2000, 46, 297-303. [CrossRef]

66. Valenzuela, A.S.; Benomar, N.; Abriouel, H.; Cañamero, M.M.; López, R.L.; Gálvez, A. Biocide and copper tolerance in enterococci from different sources. J. Food Prot. 2013, 76, 1806-1809. [CrossRef] [PubMed]

67. Kitagawa, H.; Izutani, N.; Kitagawa, R.; Maezono, H.; Yamaguchi, M.; Imazato, S. Evolution of resistance to cationic biocides in Streptococcus mutans and Enterococcus faecalis. J. Dent. 2016, 47, 18-22. [CrossRef]

68. Nasr, A.M.; Mostafa, M.S.; Arnaout, H.H.; Elshimy, A.A.A. The effect of exposure to sub-inhibitory concentrations of hypochlorite and quaternary ammonium compounds on antimicrobial susceptibility of Pseudomonas aeruginosa. Am. J. Infect. Control. 2018, 46, e57-e63. [CrossRef]

69. Hasanvand, A.; Ghafourian, S.; Taherikalani, M.; Jalilian, F.A.; Sadeghifard, N.; Pakzad, I. Antiseptic resistance in methicillin sensitive and methicillin resistant Staphylococcus aureus isolates from some major hospitals, Iran. Recent Pat. Anti-Infect. Drug Discov. 2015, 10, 105-112. [CrossRef]

70. Kernberger-Fischer, I.A. Nanosilberbeschichtete Lebensmittelverpackungsfolie zur Reduktion von Keimen auf Schweinefleisch und Testung der Empfindlichkeit von MRSA-und MSSA-Isolaten gegenüber Silber und sieben weiteren Bioziden. Ph.D. Thesis, Stiftung Tierärztliche Hochschule Hannover, Hannover, Germany, 2018.

71. Noguchi, N.; Nakaminami, H.; Nishijima, S.; Kurokawa, I.; So, H.; Sasatsu, M. Antimicrobial agent of susceptibilities and antiseptic resistance gene distribution among methicillin-resistant Staphylococcus aureus isolates from patients with impetigo and staphylococcal scalded skin syndrome. J. Clin. Microbiol. 2006, 44, 2119-2125. [CrossRef] [PubMed]

72. Noguchi, N.; Suwa, J.; Narui, K.; Sasatsu, M.; Ito, T.; Hiramatsu, K.; Song, J.-H. Susceptibilities to antiseptic agents and distribution of antiseptic-resistance genes qacA/B and smr of methicillin-resistant Staphylococcus aureus isolated in Asia during 1998 and 1999 J. Med. Microbiol. 2005, 54, 557-565. [CrossRef]

73. Buxbaum, A.; Kratzer, C.; Graninger, W.; Georgopoulos, A. Antimicrobial and toxicological profile of the new biocide Akacid plus®. J. Antimicrob. Chemother. 2006, 58, 193-197. [CrossRef]

74. Morita, Y.; Tomida, J.; Kawamura, Y. Responses of Pseudomonas aeruginosa to antimicrobials. Front. Microbiol. 2014, 4, 422. [CrossRef] [PubMed]

75. Nde, C.W.; Jang, H.-J.; Toghrol, F.; Bentley, W.E. Global transcriptomic response of Pseudomonas aeruginosa to chlorhexidine diacetate. Environ. Sci. Technol. 2009, 43, 8406-8415. [CrossRef]

76. Sheng, W.-H.; Wang, J.-T.; Lauderdale, T.-L.; Weng, C.-M.; Chen, D.; Chang, S.-C. Epidemiology and susceptibilities of methicillinresistant Staphylococcus aureus in Taiwan: Emphasis on chlorhexidine susceptibility. Diagn. Microbiol. Infect. Dis. 2009, 63, 309-313. [CrossRef]

77. Vijayakumar, R.; Sandle, T.; Al-Aboody, M.S.; AlFonaisan, M.K.; Alturaiki, W.; Mickymaray, S.; Premanathan, M.; Alsagaby, S.A. Distribution of biocide resistant genes and biocides susceptibility in multidrug-resistant Klebsiella pneumoniae, Pseudomonas aeruginosa and Acinetobacter baumannii-A first report from the Kingdom of Saudi Arabia. J. Infect. Public Health 2018, 11, 812-816. [CrossRef]

78. Fazlara, A.; Ekhtelat, M. The disinfectant effects of benzalkonium chloride on some important foodborne pathogens. Am. Eurasian. J. Agric. Environ. Sci. 2012, 12, 23-29.

79. He, G.-X.; Landry, M.; Chen, H.; Thorpe, C.; Walsh, D.; Varela, M.F.; Pan, H. Detection of benzalkonium chloride resistance in community environmental isolates of staphylococci. J. Med. Microbiol. 2014, 63, 735. [CrossRef] [PubMed]

80. Mc Cay, P.H.; Ocampo-Sosa, A.A.; Fleming, G.T. Effect of subinhibitory concentrations of benzalkonium chloride on the competitiveness of Pseudomonas aeruginosa grown in continuous culture. Microbiology 2010, 156, 30-38. [CrossRef]

81. Yu, T.; Jiang, X.; Zhang, Y.; Ji, S.; Gao, W.; Shi, L. Effect of benzalkonium chloride adaptation on sensitivity to antimicrobial agents and tolerance to environmental stresses in Listeria monocytogenes. Front. Microbiol. 2018, 9, 2906. [CrossRef] [PubMed] 
82. Tandukar, M.; Oh, S.; Tezel, U.; Konstantinidis, K.T.; Pavlostathis, S.G. Long-term exposure to benzalkonium chloride disinfectants results in change of microbial community structure and increased antimicrobial resistance. Environ. Sci. Technol. 2013, 47, 9730-9738. [CrossRef]

83. Wickham, G. An investigation into the relative resistances of common bacterial pathogens to quaternary ammonium cation disinfectants. Biosci. Horiz. Int. J. Stud. Res. 2017, 10, hzx008. [CrossRef]

84. Chung, Y.J.; Saier, M.H. Overexpression of the Escherichia coli sugE gene confers resistance to a narrow range of quaternary ammonium compounds. J. Bacteriol. 2002, 184, 2543-2545. [CrossRef]

85. Nishino, K.; Yamaguchi, A. Analysis of a complete library of putative drug transporter genes in Escherichia coli. J. Bacteriol. 2001, 183, 5803-5812. [CrossRef]

86. Abdelaziz, A.; Sonbol, F.; Elbanna, T.; El-Ekhnawy, E. Exposure to Sublethal Concentrations of Benzalkonium Chloride Induces Antimicrobial Resistance and Cellular Changes in Klebsiellae pneumoniae Clinical Isolates. Microb. Drug Resist. 2019, 25, 631-638. [CrossRef] [PubMed]

87. Alam, M.M.; Ishino, M.; Kobayashi, N. Analysis of genomic diversity and evolution of the low-level antiseptic resistance gene smr in Staphylococcus aureus. Microb. Drug Resist. 2003, 9, 1-7. [CrossRef] [PubMed]

88. Correa, J.; De Paulis, A.; Predari, S.; Sordelli, D.; Jeric, P. First report of qacG, qacH and qacJ genes in Staphylococcus haemolyticus human clinical isolates. J. Antimicrob. Chemother. 2008, 62, 956-960. [CrossRef]

89. Truong-Bolduc, Q.; Dunman, P.; Strahilevitz, J.; Projan, S.; Hooper, D. MgrA is a multiple regulator of two new efflux pumps in Staphylococcus aureus. J. Bacteriol. 2005, 187, 2395-2405. [CrossRef] [PubMed]

90. Gradel, K.O.; Randall, L.; Sayers, A.R.; Davies, R.H. Possible associations between Salmonella persistence in poultry houses and resistance to commonly used disinfectants and a putative role of mar. Vet. Microbiol. 2005, 107, 127-138. [CrossRef]

91. Pidot, S.J.; Gao, W.; Buultjens, A.H.; Monk, I.R.; Guerillot, R.; Carter, G.P.; Lee, J.Y.; Lam, M.M.; Grayson, M.L.; Ballard, S.A. Increasing tolerance of hospital Enterococcus faecium to handwash alcohols. Sci. Transl. Med. 2018, 10. [CrossRef]

92. Reimer, K.; Wichelhaus, T.; Schäfer, V.; Rudolph, P.; Kramer, A.; Wutzler, P.; Ganzer, D.; Fleischer, W. Antimicrobial effectiveness of povidone-iodine and consequences for new application areas. Dermatology 2002, 204, 114-120. [CrossRef]

93. Tschudin-Sutter, S.; Frei, R.; Kampf, G.; Tamm, M.; Pflimlin, E.; Battegay, M.; Widmer, A.F. Emergence of glutaraldehyde-resistant Pseudomonas aeruginosa. Infect. Control. Hosp. Epidemiol. 2011, 32, 1173-1178. [CrossRef]

94. Willing, B.P.; Pepin, D.M.; Marcolla, C.S.; Forgie, A.J.; Diether, N.E.; Bourrie, B.C. Bacterial resistance to antibiotic alternatives: A wolf in sheep's clothing? Anim. Front. 2018, 8, 39-47. [CrossRef]

95. National Center for Biotechnology Information. PubChem Compound Summary for CID 5564, Triclosan. Available online: https://pubchem.ncbi.nlm.nih.gov/compound/Triclosan (accessed on 19 February 2021).

96. Morrissey, I.; Oggioni, M.R.; Knight, D.; Curiao, T.; Coque, T.; Kalkanci, A.; Martinez, J.L.; Consortium, B. Evaluation of epidemiological cut-off values indicates that biocide resistant subpopulations are uncommon in natural isolates of clinicallyrelevant microorganisms. PLoS ONE 2014, 9, e86669. [CrossRef]

97. Webber, M.; Piddock, L. The importance of efflux pumps in bacterial antibiotic resistance. J. Antimicrob. Chemother. 2003, 51, 9-11. [CrossRef]

98. Penna, T.C.V.; Mazzola, P.G.; Martins, A.M.S. The efficacy of chemical agents in cleaning and disinfection programs. BMC Infect. Dis. 2001, 1, 16. [CrossRef]

99. Sella, S.R.; Guizelini, B.P.; Ribeiro, H. Validation of peracetic acid as a sporicide for sterilization of working surfaces in biological safety cabinets. J. Microbiol. Infect. Dis. 2012, 2, 93-99. [CrossRef]

100. Maertens, H.; De Reu, K.; Meyer, E.; Van Coillie, E.; Dewulf, J. Limited association between disinfectant use and either antibiotic or disinfectant susceptibility of Escherichia coli in both poultry and pig husbandry. BMC Vet. Res. 2019, 15, 310. [CrossRef]

101. Mazzola, P.G.; Jozala, A.F.; Novaes, L.C.d.L.; Moriel, P.; Penna, T.C.V. Minimal inhibitory concentration (MIC) determination of disinfectant and/or sterilizing agents. Braz. J. Pharm. Sci. 2009, 45, 241-248. [CrossRef]

102. Zhu, G.; Wang, Q.; Lu, S.; Niu, Y. Hydrogen peroxide: A potential wound therapeutic target. Med. Princ. Pract. 2017, 26, 301-308. [CrossRef]

103. Zubko, E.I.; Zubko, M.K. Co-operative inhibitory effects of hydrogen peroxide and iodine against bacterial and yeast species. BMC Res. Notes 2013, 6, 272. [CrossRef] [PubMed]

104. Handtke, S.; Albrecht, D.; Zühlke, D.; Otto, A.; Becher, D.; Schweder, T.; Riedel, K.; Hecker, M.; Voigt, B. Bacillus pumilus KatX2 confers enhanced hydrogen peroxide resistance to a Bacillus subtilis P katA:: katX2 mutant strain. Microb. Cell Factories 2017, 16, 72. [CrossRef]

105. D'Ercole, S.; Catamo, G.; De Fazio, P.; Piccolomini, R. In vitro antimicrobial activity of glutaraldehyde plus O-phenylphenol association (ratio 2:1). Minerva Stomatol. 2002, 51, 29-33.

106. Gradel, K.O.; Randall, L. Minimum Inhibitory Concentrations of and Adaptation to Five Disinfectants Commonly Used Against Salmonella in the Poultry Industry. Available online: https://www.isah-soc.org/userfiles/downloads/proceedings/2003 /speakers/S32GradelDenmark.pdf (accessed on 3 February 2021).

107. Stuart, M.C.; Kouimtzi, M.; Hill, S.R. WHO Model Formulary 2008; World Health Organization: Geneva, Switzerland, 2009.

108. Vijayakumar, R.; Sandle, T. A review on biocide reduced susceptibility due to plasmid-borne antiseptic-resistant genes-special notes on pharmaceutical environmental isolates. J. Appl. Microbiol. 2019, 126, 1011-1022. [CrossRef] [PubMed] 
109. CDC. Guideline for Disinfection and Sterilization in Healthcare Facilities, 2008. William A. Rutala, David J. Weber, Healthcare Infection Control Practices Advisory Committee (HICPAC). 2019. Available online: https:/ / www.cdc.gov/infectioncontrol/pdf/ guidelines / disinfection-guidelines-H.pdf (accessed on 3 February 2021).

110. Ramzi, A.; Oumokhtar, B.; Ez Zoubi, Y.; Filali Mouatassem, T.; Benboubker, M.; El Ouali Lalami, A. Evaluation of Antibacterial Activity of Three Quaternary Ammonium Disinfectants on Different Germs Isolated from the Hospital Environment. BioMed Res. Int. 2020, 2020, 6509740. [CrossRef] [PubMed]

111. Kouidhi, B.; Zmantar, T.; Jrah, H.; Souiden, Y.; Chaieb, K.; Mahdouani, K.; Bakhrouf, A. Antibacterial and resistance-modifying activities of thymoquinone against oral pathogens. Ann. Clin. Microbiol. Antimicrob. 2011, 10, 29. [CrossRef]

112. To, M.S.; Favrin, S.; Romanova, N.; Griffiths, M.W. Postadaptational resistance to benzalkonium chloride and subsequent physicochemical modifications of Listeria monocytogenes. Appl. Environ. Microbiol. 2002, 68, 5258-5264. [CrossRef] [PubMed]

113. Langsrud, S.; Sidhu, M.S.; Heir, E.; Holck, A.L. Bacterial disinfectant resistance-A challenge for the food industry. Int. Biodeterior. Biodegrad. 2003, 51, 283-290. [CrossRef]

114. Abreu, A.C.; Tavares, R.R.; Borges, A.; Mergulhão, F.; Simões, M. Current and emergent strategies for disinfection of hospital environments. J. Antimicrob. Chemother. 2013, 68, 2718-2732. [CrossRef]

115. Meyer, B.; Cookson, B. Does microbial resistance or adaptation to biocides create a hazard in infection prevention and control? J. Hosp. Infect. 2010, 76, 200-205. [CrossRef]

116. MIC EUCAST. MIC and Inhibition Zone Diameter Distributions of Microorganisms without and with Phenotypically Evident Resistance Mechanisms. Available online: https:/ / mic.eucast.org (accessed on 3 February 2021).

117. Lambert, P. Cellular impermeability and uptake of biocides and antibiotics in Gram-positive bacteria and mycobacteria. J. Appl. Microbiol. 2002, 92, 46S-54S. [CrossRef]

118. Tattawasart, U.; Maillard, J.-Y.; Furr, J.; Russell, A. Outer membrane changes in Pseudomonas stutzeri resistant to chlorhexidine diacetate and cetylpyridinium chloride. Int. J. Antimicrob. Agents 2000, 16, 233-238. [CrossRef]

119. Winder, C.; Al-Adham, I.; Abdel Malek, S.; Buultjens, T.; Horrocks, A.; Collier, P. Outer membrane protein shifts in biocide-resistant Pseudomonas aeruginosa PAO1. J. Appl. Microbiol. 2000, 89, 289-295. [CrossRef]

120. Olmeda-López, H.; Corral-Lugo, A.; McConnell, M.J. Effect of Subinhibitory Concentrations of Antibiotics and Disinfectants on ISAba-Mediated Inactivation of Lipooligosaccharide Biosynthesis Genes in Acinetobacter baumannii. Antibiotics 2021, 10, 1259. [CrossRef]

121. Dubois-Brissonnet, F.; Naïtali, M.; Mafu, A.A.; Briandet, R. Induction of fatty acid composition modifications and tolerance to biocides in Salmonella enterica serovar Typhimurium by plant-derived terpenes. Appl. Environ. Microbiol. 2011, 77, 906-910. [CrossRef] [PubMed]

122. Ferreira, C.; Pereira, A.; Pereira, M.; Melo, L.; Simões, M. Physiological changes induced by the quaternary ammonium compound benzyldimethyldodecylammonium chloride on Pseudomonas fluorescens. J. Antimicrob. Chemother. 2011, 66, 1036-1043. [CrossRef] [PubMed]

123. Nikaido, H. Molecular basis of bacterial outer membrane permeability revisited. Microbiol. Mol. Biol. Rev. 2003, 67, 593-656. [CrossRef]

124. Leggett, M.J.; McDonnell, G.; Denyer, S.P.; Setlow, P.; Maillard, J.Y. Bacterial spore structures and their protective role in biocide resistance. J. Appl. Microbiol. 2012, 113, 485-498. [CrossRef] [PubMed]

125. Baugh, S.; Ekanayaka, A.S.; Piddock, L.J.; Webber, M.A. Loss of or inhibition of all multidrug resistance efflux pumps of Salmonella enterica serovar Typhimurium results in impaired ability to form a biofilm. J. Antimicrob. Chemother. 2012, 67, 2409-2417. [CrossRef] [PubMed]

126. Sheldon Jr, A.T. Antiseptic "resistance": Real or perceived threat? Clin. Infect. Dis. 2005, 40, 1650-1656. [CrossRef]

127. Gilbert, P.; McBain, A.J. Potential impact of increased use of biocides in consumer products on prevalence of antibiotic resistance. Clin. Microbiol. Rev. 2003, 16, 189-208. [CrossRef]

128. Nishihara, T.; Okamoto, T.; Nishiyama, N. Biodegradation of didecyldimethylammonium chloride by Pseudomonas fluorescens TN4 isolated from activated sludge. J. Appl. Microbiol. 2000, 88, 641-647. [CrossRef]

129. Jamshidi, S.; Sutton, J.M.; Rahman, K.M. An overview of bacterial efflux pumps and computational approaches to study efflux pump inhibitors. Future Med. Chem. 2016, 8, 195-210. [CrossRef]

130. Gnanadhas, D.P.; Marathe, S.A.; Chakravortty, D. Biocides-resistance, cross-resistance mechanisms and assessment. Expert Opin. Investig. Drugs 2013, 22, 191-206. [CrossRef]

131. Blanco, P.; Hernando-Amado, S.; Reales-Calderon, J.A.; Corona, F.; Lira, F.; Alcalde-Rico, M.; Bernardini, A.; Sanchez, M.B.; Martinez, J.L. Bacterial multidrug efflux pumps: Much more than antibiotic resistance determinants. Microorganisms $2016,4,14$. [CrossRef]

132. Randall, L.; Cooles, S.; Coldham, N.; Penuela, E.; Mott, A.; Woodward, M.J.; Piddock, L.; Webber, M. Commonly used farm disinfectants can select for mutant Salmonella enterica serovar Typhimurium with decreased susceptibility to biocides and antibiotics without compromising virulence. J. Antimicrob. Chemother. 2007, 60, 1273-1280. [CrossRef] [PubMed]

133. Morita, Y.; Murata, T.; Mima, T.; Shiota, S.; Kuroda, T.; Mizushima, T.; Gotoh, N.; Nishino, T.; Tsuchiya, T. Induction of mexCD-oprJ operon for a multidrug efflux pump by disinfectants in wild-type Pseudomonas aeruginosa PAO1. J. Antimicrob. Chemother. 2003, 51, 991-994. [CrossRef] 
134. Braoudaki, M.; Hilton, A.C. Low level of cross-resistance between triclosan and antibiotics in Escherichia coli K-12 and E. coli O55 compared to E. coli O157. FEMS Microbiol. Lett. 2004, 235, 305-309.

135. Sanchez, P.; Moreno, E.; Martinez, J.L. The biocide triclosan selects Stenotrophomonas maltophilia mutants that overproduce the SmeDEF multidrug efflux pump. Antimicrob. Agents Chemother. 2005, 49, 781-782. [CrossRef] [PubMed]

136. Russell, A.D. Mechanisms of bacterial insusceptibility to biocides. Am. J. Infect. Control 2001, 29, 259-261. [CrossRef]

137. Huet, A.A.; Raygada, J.L.; Mendiratta, K.; Seo, S.M.; Kaatz, G.W. Multidrug efflux pump overexpression in Staphylococcus aureus after single and multiple in vitro exposures to biocides and dyes. Microbiology 2008, 154, 3144-3153. [CrossRef]

138. Wessels, S.; Ingmer, H. Modes of action of three disinfectant active substances: A review. Regul. Toxicol. Pharmacol. 2013, 67, 456-467. [CrossRef]

139. Aboualizadeh, E.; Bumah, V.V.; Masson-Meyers, D.S.; Eells, J.T.; Hirschmugl, C.J.; Enwemeka, C.S. Understanding the antimicrobial activity of selected disinfectants against methicillin-resistant Staphylococcus aureus (MRSA). PLoS ONE 2017, 12, e0186375. [CrossRef] [PubMed]

140. Chatterjee, I.; Somerville, G.A.; Heilmann, C.; Sahl, H.-G.; Maurer, H.H.; Herrmann, M. Very low ethanol concentrations affect the viability and growth recovery in post-stationary-phase Staphylococcus aureus populations. Appl. Environ. Microbiol. 2006, 72, 2627-2636. [CrossRef]

141. Rutala, W.A.; Weber, D.J. Disinfection and Sterilization in Health Care Facilities: An Overview and Current Issues. Infect. Dis. Clin. N. Am. 2016, 30, 609-637. Available online: https://www.ncbi.nlm.nih.gov/pmc/articles/PMC7134755/pdf/main.pdf (accessed on 3 February 2021). [CrossRef]

142. Borana, R.; Bari, S. Ethanol tolerance in Escherichia coli DH5-Alpha developed by serial exposure to sublethal doses is conferred to wild strains by horizontal gene transfer. bioRxiv 2020. [CrossRef]

143. Chen, N.H.; Djoko, K.Y.; Veyrier, F.J.; McEwan, A.G. Formaldehyde stress responses in bacterial pathogens. Front. Microbiol. 2016, 7, 257. [CrossRef]

144. Cloete, T.E. Resistance mechanisms of bacteria to antimicrobial compounds. Int. Biodeterior. Biodegrad. 2003, 51, $277-282$. [CrossRef]

145. Yu, R.; Lai, Y.; Hartwell, H.J.; Moeller, B.C.; Doyle-Eisele, M.; Kracko, D.; Bodnar, W.M.; Starr, T.B.; Swenberg, J.A. Formation, accumulation, and hydrolysis of endogenous and exogenous formaldehyde-induced DNA damage. Toxicol. Sci. 2015, 146, 170-182. [CrossRef] [PubMed]

146. Coenye, T.; Van Acker, H.; Peeters, E.; Sass, A.; Buroni, S.; Riccardi, G.; Mahenthiralingam, E. Molecular mechanisms of chlorhexidine tolerance in Burkholderia cenocepacia biofilms. Antimicrob. Agents Chemother. 2011, 55, 1912-1919. [CrossRef]

147. Heath, R.J.; Li, J.; Roland, G.E.; Rock, C.O. Inhibition of the Staphylococcus aureus NADPH-dependent enoyl-acyl carrier protein reductase by triclosan and hexachlorophene. J. Biol. Chem. 2000, 275, 4654-4659. [CrossRef]

148. Lu, J.; Jin, M.; Nguyen, S.H.; Mao, L.; Li, J.; Coin, L.J.; Yuan, Z.; Guo, J. Non-antibiotic antimicrobial triclosan induces multiple antibiotic resistance through genetic mutation. Environ. Int. 2018, 118, 257-265. [CrossRef] [PubMed]

149. Khan, R.; Roy, N.; Choi, K.; Lee, S.-W. Distribution of triclosan-resistant genes in major pathogenic microorganisms revealed by metagenome and genome-wide analysis. PLoS ONE 2018, 13, e0192277. [CrossRef]

150. Pycke, B.F.; Crabbé, A.; Verstraete, W.; Leys, N. Characterization of triclosan-resistant mutants reveals multiple antimicrobial resistance mechanisms in Rhodospirillum rubrum S1H. Appl. Environ. Microbiol. 2010, 76, 3116-3123. [CrossRef]

151. Schweizer, H.P. Triclosan: A widely used biocide and its link to antibiotics. FEMS Microbiol. Lett. 2001, 202, 1-7. [CrossRef]

152. Bigliardi, P.L.; Alsagoff, S.A.L.; El-Kafrawi, H.Y.; Pyon, J.-K.; Wa, C.T.C.; Villa, M.A. Povidone iodine in wound healing: A review of current concepts and practices. Int. J. Surg. 2017, 44, 260-268. [CrossRef]

153. Lachapelle, J.-M.; Castel, O.; Casado, A.F.; Leroy, B.; Micali, G.; Tennstedt, D.; Lambert, J. Antiseptics in the era of bacterial resistance: A focus on povidone iodine. Clin. Pract. 2013, 10, 579. [CrossRef]

154. Capriotti, K.; Pelletier, J.; Barone, S.; Capriotti, J. Efficacy of dilute povidone-iodine against multi-drug resistant bacterial biofilms, fungal biofilms and fungal spores. Clin. Res. Dermatol. 2018, 5, 1-5.

155. Linley, E.; Denyer, S.P.; McDonnell, G.; Simons, C.; Maillard, J.-Y. Use of hydrogen peroxide as a biocide: New consideration of its mechanisms of biocidal action. J. Antimicrob. Chemother. 2012, 67, 1589-1596. [CrossRef] [PubMed]

156. Baureder, M.; Reimann, R.; Hederstedt, L. Contribution of catalase to hydrogen peroxide resistance in Enterococcus faecalis. FEMS Microbiol. Lett. 2012, 331, 160-164. [CrossRef]

157. Mah, T.-F.C.; O'Toole, G.A. Mechanisms of biofilm resistance to antimicrobial agents. Trends Microbiol. 2001, 9, 34-39. [CrossRef]

158. Bondurant, S.; McKinney, T.; Bondurant, L.; Fitzpatrick, L. Evaluation of a benzalkonium chloride hand sanitizer in reducing transient Staphylococcus aureus bacterial skin contamination in health care workers. Am. J. Infect. Control. 2020, 48, 522-526. [CrossRef]

159. Gravel, J.; Paradis-Bleau, C.; Schmitzer, A.R. Adaptation of a bacterial membrane permeabilization assay for quantitative evaluation of benzalkonium chloride as a membrane-disrupting agent. Medchemcomm 2017, 8, 1408-1413. [CrossRef] [PubMed]

160. Mc Carlie, S.; Boucher, C.E.; Bragg, R.R. Molecular basis of bacterial disinfectant resistance. Drug Resist. Updates 2020, $48,100672$. [CrossRef] [PubMed]

161. Bragg, R.; Jansen, A.; Coetzee, M.; van der Westhuizen, W.; Boucher, C. Bacterial resistance to Quaternary Ammonium Compounds (QAC) disinfectants. Adv. Exp. Med. Biol. 2014, 808, 1-13. [CrossRef] [PubMed] 
162. Roca, I.; Akova, M.; Baquero, F.; Carlet, J.; Cavaleri, M.; Coenen, S.; Cohen, J.; Findlay, D.; Gyssens, I.; Heuer, O.E.; et al. The global threat of antimicrobial resistance: Science for intervention. New Microbes New Infect. 2015, 6, 22-29. [CrossRef]

163. Tong, C.; Hu, H.; Chen, G.; Li, Z.; Li, A.; Zhang, J. Disinfectant resistance in bacteria: Mechanisms, spread, and resolution strategies. Environ. Res. 2021, 195, 110897. [CrossRef]

164. Murtough, S.M.; Hiom, S.J.; Palmer, M.; Russell, A.D. Biocide rotation in the healthcare setting: Is there a case for policy implementation? J. Hosp. Infect. 2001, 48, 1-6. [CrossRef] [PubMed]

165. Davis, M.A.; Sischo, W.M.; Jones, L.P.; Moore, D.A.; Ahmed, S.; Short, D.M.; Besser, T.E. Recent Emergence of Escherichia coli with Cephalosporin Resistance Conferred by blaCTX-M on Washington State Dairy Farms. Appl. Environ. Microbiol. 2015, 81, 4403-4410. [CrossRef] [PubMed]

166. Madigan, M.T.; Martinko, J.M.; Bender, K.S.; Buckley, D.H.; Stahl, D.A. Brock Biology of Microorganisms, 14th ed.; Pearson: London, UK, 2015.

167. Hardy, K.; Sunnucks, K.; Gil, H.; Shabir, S.; Trampari, E.; Hawkey, P.; Webber, M. Increased usage of antiseptics is associated with reduced susceptibility in clinical isolates of Staphylococcus aureus. MBio 2018, 9, e00894-18. [CrossRef]

168. O'Neill, J. Tackling Drug Resistant Infections Globally-Final Report and Recommendations; Government of the United Kingdom: London, UK, 2016. 